Energy Efficiency and Renewable Energy Research, Development, and Deployment in Meeting Greenhouse Gas Mitigation Goals: The Case of the Lieberman-Warner Climate Security Act of 2007 (S. 2191)

Sharon Showalter and Frances Wood OnLocation, Inc. / Energy Systems Consulting Vienna, Virginia

Laura Vimmerstedt National Renewable Energy Laboratory Golden, Colorado
Technical Report NREL/TP-6A2-47213 June 2010 


\section{Energy Efficiency and Renewable Energy Research, Development, and Deployment in Meeting Greenhouse Gas Mitigation Goals: The Case of the Lieberman-Warner Climate Security Act of 2007 (S. 2191)}

Sharon Showalter and Frances Wood

OnLocation, Inc. / Energy Systems Consulting

Vienna, Virginia

Laura Vimmerstedt

National Renewable Energy Laboratory

Golden, Colorado

Prepared under Task No. SAO9.1051

National Renewable Energy Laboratory

1617 Cole Boulevard, Golden, Colorado 80401-3393

303-275-3000 • www.nrel.gov

NREL is a national laboratory of the U.S. Department of Energy

Office of Energy Efficiency and Renewable Energy

Operated by the Alliance for Sustainable Energy, LLC

Contract No. DE-AC36-08-GO28308

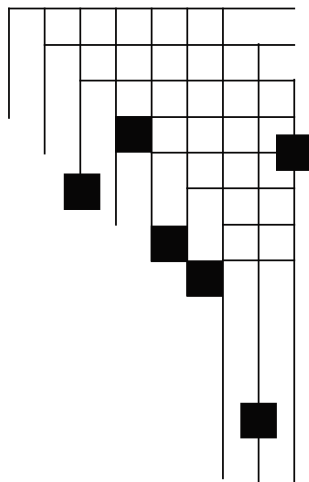




\section{NOTICE}

This report was prepared as an account of work sponsored by an agency of the United States government. Neither the United States government nor any agency thereof, nor any of their employees, makes any warranty, express or implied, or assumes any legal liability or responsibility for the accuracy, completeness, or usefulness of any information, apparatus, product, or process disclosed, or represents that its use would not infringe privately owned rights. Reference herein to any specific commercial product, process, or service by trade name, trademark, manufacturer, or otherwise does not necessarily constitute or imply its endorsement, recommendation, or favoring by the United States government or any agency thereof. The views and opinions of authors expressed herein do not necessarily state or reflect those of the United States government or any agency thereof.

Available electronically at http://www.osti.gov/bridge

Available for a processing fee to U.S. Department of Energy and its contractors, in paper, from:

U.S. Department of Energy

Office of Scientific and Technical Information

P.O. Box 62

Oak Ridge, TN 37831-0062

phone: 865.576 .8401

fax: 865.576 .5728

email: mailto:reports@adonis.osti.gov

Available for sale to the public, in paper, from:

U.S. Department of Commerce

National Technical Information Service

5285 Port Royal Road

Springfield, VA 22161

phone: 800.553.6847

fax: 703.605.6900

email: orders@ntis.fedworld.gov

online ordering: http://www.ntis.gov/ordering.htm 


\section{Table of Contents}

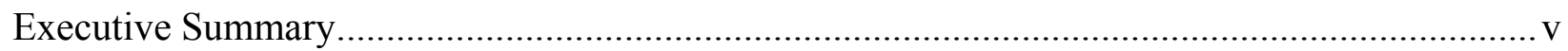

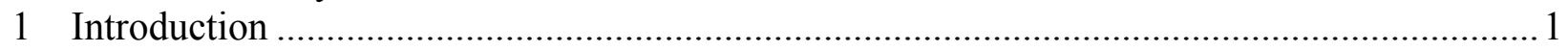

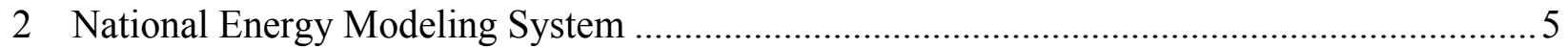

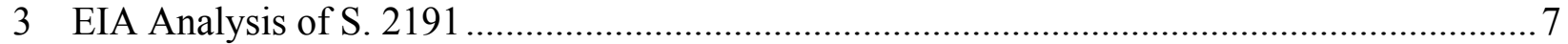

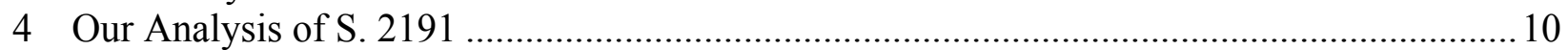

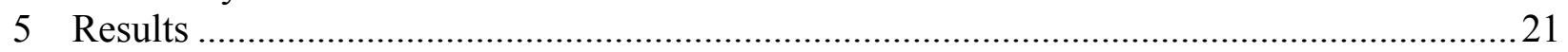

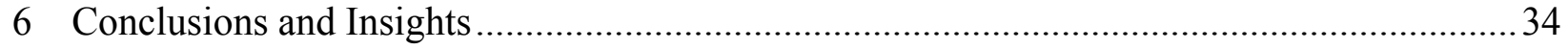




\section{List of Figures}

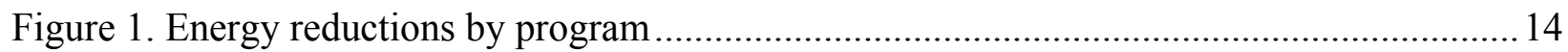

Figure 2. Cellulosic ethanol investment cost........................................................................ 16

Figure 3. Covered greenhouse gas emissions less offsets ....................................................... 21

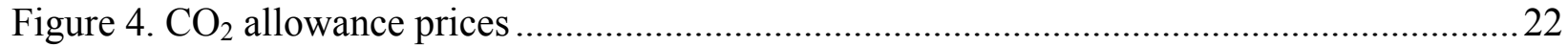

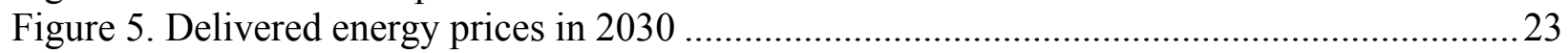

Figure 6. Energy-related $\mathrm{CO}_{2}$ emission reductions from EIA base...........................................2.

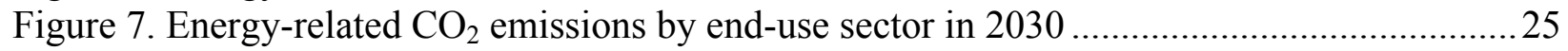

Figure 8. Primary energy consumption by fuel ................................................................... 25

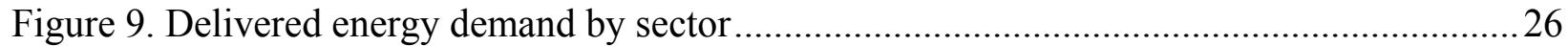

Figure 10. Growth in delivered energy demand in years 2010-2030 ........................................2. 26

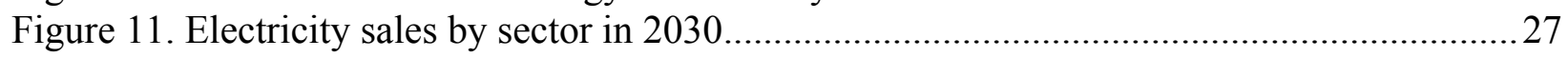

Figure 12. Electric generating capacity, including distributed generating capacity......................28

Figure 13. Renewable electric capacity, including distributed generating capacity .....................28

Figure 14. Electricity generation, including distributed generating capacity ................................2.29

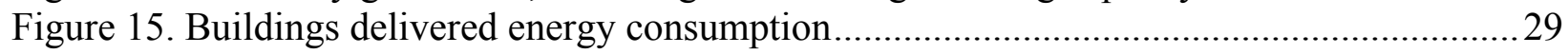

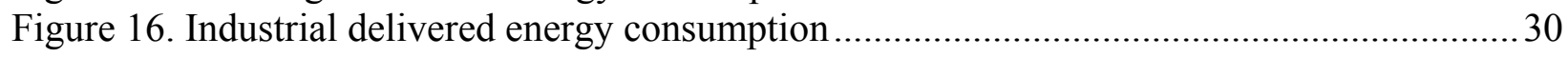

Figure 17. Transportation energy consumption by mode........................................................... 31

Figure 18. Fuel efficiency for new light-duty and heavy-duty vehicles........................................31

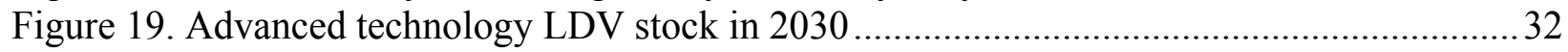

Figure 20. Ethanol production by source ………................................................................... 33

\section{List of Tables}

Table 1. Modeling Methodology for Each EERE Program ............................................................. 13

Table 2. Comparison of NEMS-EERE and EIA Vehicle Assumptions in 2030 ............................15

Table 3. Comparison of NEMS-EERE and EIA Renewable Generation Technology

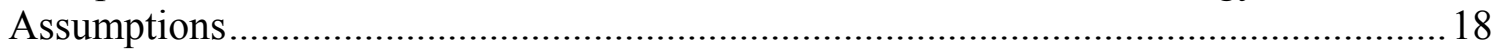

Table 4. EIA Fossil Generation Technology Assumptions ............................................................. 19 


\section{Executive Summary}

The U.S. Congress and the Obama administration are considering legislative and administrative actions that would limit nationwide greenhouse gas emissions. Renewable energy and energy efficiency (RE/EE) technologies could play an important role in efforts to reduce greenhouse gas emissions from energy use in the United States. Accordingly, the cost of these technologies could significantly influence the overall cost of reducing greenhouse gas emissions. This paper, which presents an analysis of the Lieberman-Warner Climate Security Act of 2007 (S. 2191), examines the potential for (RE/EE) technology improvements to reduce the cost of greenhouse gas mitigation.

Senators Joseph Lieberman (I-Conn.) and John Warner (R-Va.) introduced S. 2191 in October 2007. If passed, it would have established a nationwide cap-and-trade allowance system for greenhouse gas emissions. The Act had a goal of reducing emissions to 72 percent below 2006 emissions by 2050. Senators Lieberman and Warner subsequently requested that the U.S. Department of Energy's Energy Information Administration (EIA) analyze the effects of their proposed legislation on the U.S. energy sector. Results of the EIA analysis include the projected cost of compliance and the effect of different energy technologies on market share.

In this report, we present results of an analysis of S. 2191 conducted for the U.S. Department of Energy's Office of Energy Efficiency and Renewable Energy (EERE). Our analysis was similar to the EIA analysis but used modified technology assumptions to reflect EERE program goals for EERE's portfolio of federally funded research, development, and deployment efforts that target further cost reductions in and accelerated adoption of a variety of renewable energy and energy efficiency technologies.

Both our analysis and the EIA analysis examine the impacts of S. 2191; both use versions of the National Energy Modeling System; and both use the same assumptions for all model inputs except the RE/EE technology characteristics and EERE program impacts. Our results show that achieving EERE program goals could reduce greenhouse gas allowance prices (and electricity prices) needed to meet target emission reductions and reduce energy intensity. EERE programs are also projected to reduce the cost of renewable electricity generation and transportation biofuels, allowing greater adoption of these technologies. Successful achievement of EERE goals thus could enhance the ability of the U.S. economy to thrive while simultaneously mitigating greenhouse gas emissions.

Although S. 2191 did not pass into law, several subsequent proposed "climate bills" have been patterned after this legislation. By studying the potential effects of the bill with and without EERE's Research, Development and Deployment portfolio, we can gain insight into the potential energy and economic savings that the EERE programs may provide in a carbonconstrained economy. Similarly, the EERE program results represented here reflect a variety of assumptions related to program success and funding levels, all of which will likely change over time. Therefore, the results are presented here as representative of the impact that a greater emphasis on energy efficiency and renewable energy research and deployment could have on the cost of greenhouse gas mitigation. 


\section{Introduction}

On October 18, 2007, Senators Joseph Lieberman (I-CT) and John Warner (R-VA) introduced Senate bill S. 2191 in the 110th Congress. ${ }^{1}$ Titled "America's Climate Security Act of 2007," this legislation, if passed, would have established a nationwide cap-and-trade allowance system for greenhouse gas emissions with a goal of reducing emissions to levels 70 percent below 2005 emissions by 2050. The Senate bill was referred to the Committee on Environment and Public Works, which issued a substitute amendment in December 2007. Although Senator Barbara Boxer (D-Ca.) introduced a subsequent amendment in May 2008, the bill was never put to a vote. However, this bill marked the first comprehensive climate bill to be introduced for debate in the Senate, and it created a starting point for future proposed climate change legislation such as the Waxman-Markey and Boxer-Kerry bills introduced in 2009 and ongoing legislative efforts in $2010 .^{2}$

In November 2007, Senators Lieberman and Warner requested that the U.S. Energy Information Administration (EIA) analyze the effects of the proposed S. 2191 bill on the U.S. energy sector. In April 2008, EIA published the resulting report, ${ }^{3}$ which focused on the Committee's December 2007 version of the bill.

Our analysis is similar to the EIA analysis in many respects: both analyze the potential economic impacts of S. 2191; and both use versions of the National Energy Modeling System (NEMS). ${ }^{4}$ Both analyses also share the same energy market and technology assumptions used in the EIA Annual Energy Outlook (AEO) $2008^{5}$ except for some renewable energy and energy efficiency (RE/EE) technology characteristics that were modified for our analysis. Unlike the EIA analysis, our analysis does not include sensitivity analyses but instead focuses on the EIA Core S. 2191 Case that assumes low-carbon technologies such as nuclear and carbon capture and storage (CCS), as well as international offsets, are available in a timely manner to meet the bill's requirements. In addition, our analysis uses a version of NEMS that has been modified to reflect program goals of the U.S. Department of Energy's Office of Energy Efficiency and Renewable Energy (EERE). ${ }^{6}$ These program goals reflect the quantitative objectives of federally funded research, development, deployment, and

\footnotetext{
${ }^{1}$ S. 2191: Lieberman-Warner Climate Security Act of 2007. For more information, see http://www.govtrack.us/ congress/bill.xpd?bill=s110-2191.

${ }^{2}$ The text of S. 2191, the Waxman-Markey bill (H.R. 2454, the "American Clean Energy and Security Act of 2009"), and the Boxer-Kerry bill (S.1733, the "Clean Energy Jobs and American Power Act") can be found on the Library of Congress' THOMAS Web site (http://thomas.loc.gov/).

3 "Energy Market and Economic Impacts of S. 2191, the Lieberman-Warner Climate Security Act of 2007," Energy Information Administration Office of Integrated Analysis and Forecasting, SR/OIAF/2008-01, April 2008.

${ }^{4}$ Model documentation can be found on EIA's Web site (http://www.eia.doe.gov/oiaf/forecasting.html)

${ }^{5}$ For a complete description of these assumptions, refer to "Assumptions to the Annual Energy Outlook 2008," Energy Information Administration Office of Integrated Analysis and Forecasting, DOE/EIA-0554(2008), June 2008.

${ }^{6}$ EERE leads federally funded research, development, and deployment efforts that target further cost reductions in and accelerated adoption of a variety of renewable energy and energy efficiency technologies. EERE programs are projected to increase the efficiency of the energy system and decrease the cost of renewable generation. In combination with climate policy, these improvements can reduce the cost of meeting a greenhouse gas emissions cap. For more information about EERE programs, visit http://www.eere.energy.gov/.
} 
demonstration at budget levels proposed in the DOE FY2010 budget request for Congress published in May 2009. ${ }^{7}$ EERE leads federally funded research, development, and deployment efforts that target further cost reductions in these technologies and accelerate adoption of RE/EE technologies. Estimated technology costs and characteristics used in the analysis reflect the expected outcome of EERE program activities from FY2010 forward and assume that program goals are met but do not reflect any technology development or deployment efforts outside the scope of EERE programs such as state or international efforts that are already reflected in the EIA AEO Reference Cases. Therefore, by design, this study isolates the effect of RE/EE technologies, rather than exploring the more general effect of improved energy technology performance and adoption. Also, our study focuses on a single set of RE/EE improvements as reflected in EERE program goals and does not broadly explore implications of diverse RE/EE improvement paths.

Differences in results between our analysis and the EIA analysis show the potential effect of the EERE program portfolio on reducing the cost of greenhouse gas mitigation. Renewable energy and energy efficiency technologies could play an important role in mitigating greenhouse gas emissions from energy use in the United States. Accordingly, EERE programs that reduce the cost of these technologies could reduce the cost of greenhouse gas mitigation. Our results suggest if EERE programs achieve their goals, the costs of compliance with proposed greenhouse gas mitigation goals would be lower, thereby reducing the consumer energy cost increases associated with greenhouse gas mitigation. Our results also suggest that reaching these goals could alter the relative market share of different energy technologies under the legislatively proposed emission constraint and could reduce the energy intensity of the energy system over the next 20 years.

Although S. 2191 did not pass into law, several subsequent proposed climate bills have been patterned after this legislation. Due to the length of time needed to prepare this analysis and the similarities in the overall climate goals of the bills subsequent to S. 2191, we chose to focus on the S. 2191 instead of shifting to a moving target. By studying the potential effects of the bill with and without EERE's Research, Development and Deployment (RD\&D) portfolio, we can gain insight into the potential energy and economic savings that the EERE programs may provide in a carbon-constrained economy. Similarly, the EERE program results represented here reflect a variety of assumptions related to program success and funding levels, all of which will likely change over time. Therefore, the results are presented here as representative of the impact that a greater emphasis on RE/EE research and deployment could have on the cost of greenhouse gas mitigation.

As a computer model, NEMS cannot predict the future nor represent all aspects of comprehensive climate legislation like S. 2191. Analysts' judgment plays a major role in determining the technology and policy assumptions that will drive the results of any analysis of energy markets, including the analyses discussed here.

\footnotetext{
${ }^{7}$ The budget documents can be viewed at the Web site of the DOE Office of the Chief Financial Officer (http://www.cfo.doe.gov/budget/10budget/start.htm\#Summary Budget Documents)
} 


\section{S. 2191 Provisions}

Senators Lieberman and Warner introduced S. 2191 to mitigate the effects of U.S. greenhouse gas emissions on the global climate. If passed, S. 2191 would have established a cap-andtrade allowance system for greenhouse gas emissions, reducing covered emissions to meet these goals:

- 7 percent below 2006 levels starting in 2012

- 39 percent below 2006 levels by 2030

- 72 percent below 2006 levels by 2050 .

S. 2191 proposed regulation of approximately 87 percent of total greenhouse gases, including most sources of carbon dioxide $\left(\mathrm{CO}_{2}\right)$, methane $\left(\mathrm{CH}_{4}\right)$, nitrous oxide $\left(\mathrm{N}_{2} \mathrm{O}\right)$, and three classes of fluorinated gases: hydrofluorocarbons (HFCs), perfluorocarbons (PFCs), and sulfur hexafluoride $\left(\mathrm{SF}_{6}\right)$. Covered entities were primarily coal-fired power plants and industrial facilities, natural gas producers, petroleum refiners, and producers and importers of fluorinated gases. Sources exempt from meeting the cap included most non- $\mathrm{CO}_{2}$ agricultural emissions and methane from coal mines and landfills. Most HFC emissions were covered under a separate cap established in the bill, but in this analysis were treated as exempt.

In a cap-and-trade allowance system, such as that proposed under S. 2191, covered entities would be required to report their greenhouse gas emissions annually and submit a matching number of government-issued allowances, offset credits, or both (each allowance and credit is equivalent to one metric ton of carbon dioxide equivalent or $\mathrm{CO}_{2} \mathrm{e} .{ }^{8}$ Some tradable allowances would be distributed free of charge to covered entities, and the remainder would be auctioned by the government. Distribution of allowances for free is used to achieve objectives such as smoothing the transition to a carbon constraint for covered entities and providing rate relief for consumers. In S. 2191, the share of allowances that would be auctioned (including early auction incentives) starts at about 26 percent in 2012 and increases to about 63 percent by 2030, as specified in Title III of the bill. ${ }^{9}$

The funds raised through allowance auctions would primarily be used to fund deployment of emissions reduction technologies, to mitigate economic impacts of the policy on energy consumers through rebates and subsidies for energy-efficient appliances, and to strengthen building efficiency codes.

Covered entities would be able to meet up to 30 percent of their allowance obligation with tradable offset credits that are generated from government certified emissions reductions from non-covered domestic sources and from non-U.S. sources of greenhouse gases. Covered entities that hold allowances or offset credits in excess of the annual requirement can bank them for future use. "Banking" like this allows covered entities to over-comply in early years when the requirements are less stringent and use excess allowances in future years.

\footnotetext{
${ }^{8}$ Emissions of non- $\mathrm{CO}^{2}$ greenhouse gases are commonly measured in carbon dioxide equivalent units, calculated by multiplying their emissions (in metric tons) by their estimated global warming potential. For more information, see the U.S. Environmental Agency's glossary of climate change terms (http://www.epa.gov/ climatechange/glossary.html).

${ }^{9}$ A chart showing the allowance allocation shares may be found in EPA's presentation on S. 2191 at http://www.epa.gov/climatechange/downloads/s2191_EPA_Analysis.pdf.
} 
S. 2191 was approved by the Senate Committee on Environment and Public Works in December 2007 and was debated in the Senate in May 2008 with amendments added by Senator Boxer. Although the bill never went to a vote in the Senate, it was the first climate bill to be approved by a Senate committee, and it inspired similar legislation. This report remains of interest for studying the general effects of RD\&D programs on GHG emission reductions and their costs, even as the specific provisions of climate legislation evolve.

Section 2 describes the National Energy Modeling System (NEMS), which was used in both our analysis and in the EIA analysis of S. 2191. Section 3 describes the EIA analysis of S. 2191 using NEMS. Our analytic methods are presented in Section 4, and results of our analysis compared to the EIA S. 2191 analysis are covered in Section 5. Section 6 summarizes our conclusions and insights. 


\section{National Energy Modeling System}

The National Energy Modeling System (NEMS) ${ }^{10}$ is a publicly available model developed and maintained by EIA. It simulates the behavior of U.S. energy markets for use in evaluating midterm forecasts and policy impacts. NEMS can be used to estimate U.S. energy, economic, and environmental impacts of alternative energy policies and of different assumptions about energy markets and technologies. EIA uses NEMS to produce its AEO projections and to respond to congressional and agency requests for energy and environmental policy analysis. For this study, the National Renewable Energy Laboratory subcontracted with OnLocation, Inc./Energy Systems Consulting to perform modeling and analysis using NEMS. OnLocation is able to acquire the model and its updates from EIA and modify NEMS' structure, assumptions, or both, in order to analyze proposed energy and environmental policies. OnLocation also modifies the model to estimate RD\&D benefits for offices within DOE, including for EERE. The model modifications and assumptions needed to create the model for EERE, referred to here as NEMS-EERE, ${ }^{11}$ are described in detail in Section 4.

NEMS balances energy supply and demand in each year through energy prices, accounting for the economic competition between the various energy fuels and sources. NEMS is organized as a modular system, with a separate module representing each of the domestic fuel production markets, fuel conversion sectors, and end-use energy consuming sectors:

- Four supply modules (oil and gas, natural gas transmission and distribution, coal, and renewable fuels)

- Two conversion modules (electricity and petroleum refineries)

- Four end-use demand modules (residential, commercial, transportation, and industrial)

- Macroeconomic Activity Module ${ }^{12}$ to simulate energy/economy interactions

- International energy module to simulate world oil markets

- Integrating module that provides the mechanism to achieve a general market equilibrium among all the other modules

- Environmental module that tracks greenhouse gas emissions and the revenues associated with $\mathrm{CO}_{2}$ cap-and-trade policies.

The primary flows of information between each of these modules are the delivered prices of energy and the quantities supplied and consumed each year by region and by sector. The delivered fuel prices include the cost to produce, import, and transport fuels to the end user. End-use consumption is primarily a function of macroeconomic activity, technology choice,

\footnotetext{
${ }^{10}$ For model documentation and detailed information about the model structure, see http://www.eia.doe.gov/ oiaf/aeo/overview/.

${ }^{11}$ EIA approves the use of the name NEMS to describe only an official AEO version of the model without any modification to code or data. Because our analysis entailed minor code modifications and ran the model under various policy scenarios that deviate from AEO assumptions, the name NEMS-EERE refers to the model as used here.

${ }^{12}$ The Macroeconomic Activity Module is developed and maintained by IHS Global Insight, Inc.
} 
capital stock turnover, and short-term demand elasticities that reflect price responses (such as adjusting thermostats).

NEMS includes regional detail to represent the regional differences in energy markets, to estimate policy impacts at the regional level, and to model the costs and limitations in transportation flows of fuel from supply regions to demand regions. The level of regional detail for each module reflects the unique structure of each sector: nine U.S. Census divisions for the end-use demand modules; production and consumption regions specific to oil, natural gas, and coal supply and distribution; 13 North American Electric Reliability Council (NERC) regions and sub-regions for electricity; and five Petroleum Administration for Defense Districts for refineries.

A key feature of NEMS is the representation of technology and its improvement over time. Five of the sectors - residential, commercial, transportation, electricity generation, and refining - include extensive treatment of individual technologies and their characteristics, such as the initial capital cost, operating cost, date of availability, energy efficiency, and other sector-specific characteristics. Endogenous learning functions are used for several technologies to model the effect of "learning by doing", with costs improving as installed capacity increases. The cost and characteristics of most other technologies are specified as a function of time.

In each of these five sectors, equipment choices are made for individual technologies based primarily on economic criteria, as new equipment is needed to meet growing demand for energy services or to replace retired equipment. In the other sectors - industrial, oil and gas supply, and coal supply - the treatment of technologies is more limited due to a lack of data on individual technologies and because of the complex nature of energy-related decisions that may incorporate non-energy factors (such as labor productivity in industry).

In a greenhouse gas cap-and-trade scenario, the model calculates an allowance price per ton of $\mathrm{CO}_{2} \mathrm{e}$ in each year that reflects the system-wide cost of meeting the required reduction in emissions, subject to allowance banking requirements. If banking is available, the allowance price increases at a real discount rate of 7.4 percent to reflect the assumed rate of return required for large capital investments such as power plants. The allowance price is reflected in delivered energy prices to covered entities. 


\section{EIA Analysis of S. 2191}

On November 9, 2007, Senators Lieberman and Warner asked the EIA to analyze the potential economic impact of S. 2191 on the U.S. energy sector. Results of the EIA analysiswhich were published in April $2008^{13}$ and which reflect the version of the bill approved by the Senate Committee in December 2007-include the projected cost of compliance and effect on market share of different energy technologies. The version of NEMS used for the EIA analysis and many of the modeling assumptions used for the EIA analysis are the basis for our analysis, and the EIA results are used as a point of comparison.

EIA performed its analysis using the version of the NEMS model that was used for AEO $2008 .{ }^{14}$ EIA developed modeling assumptions such as projected technology costs and characteristics, fuel prices and availability, and market behavior for the AEO 2008, and EIA used these in their analysis of S. 2191. These assumptions are described in detail in the AEO assumptions document. ${ }^{15}$

For their analysis, EIA developed an S. 2191 Core Case that assumed that both low-carbon technologies (such as nuclear and CCS) as well as international offsets were available in a timely manner to meet the bill's requirements. In addition, EIA was asked to do sensitivity cases to vary the availability of low-carbon technologies and international offsets, but these cases are not discussed in this paper. Key policy assumptions that EIA used to model the S. 2191 Core Case, and that we adopted for our analysis, include:

- Covered entities encompass all sources of energy-related $\mathrm{CO}_{2}$ including electricity generation, transportation (through refineries), and the residential, commercial, and industrial sectors. Covered entities must obtain allowances equivalent to their emissions. The model calculates allowance price based on the cost and availability of options to mitigate greenhouse gases and reflects compliance costs in the delivered price of fossilbased energy (coal, oil and gas) consumed by these sectors.

- Covered gases are assumed to include energy-related carbon dioxide, methane from natural gas and oil systems, methane and nitrous oxide emissions from stationary combustion and mobile sources, and fluorinated gases except most HFCs that are treated in the bill under a separate cap.

- Offset credit limits are defined as 15 percent of allowances for domestic offsets (noncovered entities and domestic biogenic carbon sequestration) and 15 percent for international offsets for a total limit of 30 percent.

- The supply and pricing of all non- $\mathrm{CO}_{2}$ gas reductions and offset projects, which include domestic carbon sequestration and international offset projects, were derived by EIA from

\footnotetext{
13 "Energy Market and Economic Impacts of S. 2191, the Lieberman-Warner Climate Security Act of 2007," Energy Information Administration Office of Integrated Analysis and Forecasting, SR/OIAF/2008-01, April 2008.

${ }^{14}$ Energy Information Administration, “Annual Energy Outlook 2008 with Projections to 2030,” DOE/EIA0383(2008), June 2008.

${ }^{15}$ Energy Information Administration, “Assumptions to the Annual Energy Outlook 2008,” DOE/EIA0554(2008), June 2008.
} 
data developed by the U.S. Environmental Protection Agency and discounted to reflect EIA's views such as exclusion of forestry projects from developing countries.

- The NEMS model projects energy supply, demand, and prices through 2030, and the analysis did not address the impact of S. 2191 provisions thereafter. EIA assumed that the allowance bank balance in 2030 should be about 5 billion allowances in order to satisfy the need for allowances in the years after 2030. A real discount rate of 7.4 percent was used for banking to reflect the assumed rate of return required for large capital investments such as power plants.

- The value of allowances, allocated each year by distribution or auction as specified in Title III, is represented in the model as follows:

- The value of free allowances allocated to generators is reflected in the model as reduced electricity rates in regulated cost of service regions. The share of these allowances declines from 19 percent in 2012 to 1 percent in 2030.

- The value of free allowances allocated to local electricity distribution companies and electric cooperatives is reflected in the model as a reduction in the distribution portion of the delivered electricity price to consumers in all regions. Ten percent of the allowances are allocated this way.

- Bonus allowances available to fossil generators with CCS technology are represented in the model as payments calculated per ton of sequestered carbon and constitute an initial 4 percent of allowances that are phased out by 2035 .

- Allowance auction funds that are used to provide consumer rebates for energy efficient appliances are represented in the model as reduced incremental costs of the most efficient technologies.

- Incentives for strengthening building codes are represented in the EIA S. 2191 report by making some building efficiency packages obsolete; however, the building code improvements were not included in NEMS-EERE to avoid double counting with the shell improvement assumptions attributed to EERE programs.

- Remaining auction proceeds are modeled in the macroeconomic module of NEMS and they are used to fund research for low-carbon technologies such as CCS (reflected as increased government spending) to reduce the economic impact on businesses and consumers (through lump-sum payments) and to maintain the federal deficit at baseline levels.

Other policy assumptions for the EIA Core S. 2191 Case, along with the assumptions and results of the sensitivity cases, are described in detail in the EIA S. 2191 report. The same assumptions were adopted for our analysis except where otherwise noted.

There are uncertainties in technology and policy assumptions that have a significant impact on the model results. Our study did not address sensitivity analyses to explore these uncertainties. Some of the key areas of uncertainty are:

- The future cost and availability of low-carbon technologies such as nuclear and CCS are unclear. The next generation of nuclear plants and commercial-scale CCS plants has not 
yet been built in the United States. Issues related to siting, public acceptance, and technological progress can affect the expected cost and timing of these technologies.

- The cost and availability of carbon offsets, especially international offsets, can be affected by the regulatory requirements that have yet to be determined, as well as by international agreements with eligible suppliers.

- The assumption that covered entities will need to bank 5 billion tons by 2030 to meet post-2030 emission reductions is highly speculative. For example, a technological breakthrough could result in an inexpensive carbon-free solution that would be readily available and would reduce or eliminate the need for banked allowances. Assumptions related to banking can have a significant impact on the expected allowance price and the cost of the policy. 


\section{Our Analysis of S. 2191}

Each year, EERE performs a prospective benefits analysis of its programs-as part of its overall planning, budget, and analysis cycle - to support implementation of the requirements of the Government Performance and Results Act (GPRA) of 1993. ${ }^{16}$ Major features of EERE's program benefits analysis include:

- Benefits are estimated across EERE's entire portfolio and for each of the individual programs.

- Analysis supports EERE's annual Congressional Budget Request.

- Two different models are used as integrating frameworks for analysis: NEMS-EERE for the mid-term (to $2030^{17}$ ) and MARKAL ${ }^{18}$ for the long-term (to 2050).

- Economic, environmental, and energy security metrics are quantified.

- Benefits estimates reflect only the potential future benefits that would be attributable to the proposed EERE portfolio. Neither historical advances due to EERE programs nor advances due to non-DOE efforts are included in the benefits estimates.

For the GPRA FY2010 benefits analysis completed in May 2009, model modifications were made by OnLocation to the EIA NEMS AEO 2008 model in order to represent key aspects of the EERE program goals. The resulting NEMS-EERE model was used as an integrated modeling framework for the GPRA FY2010 analysis, and it is the model used in this study. NEMS-EERE includes these model enhancements:

- Addition of a hydrogen production and delivery module along with modifications to the representation of fuel cell, light-duty vehicle markets in the transportation module

- Enhancements to the distributed generation technology representation especially for solar photovoltaics $^{19}$

- Expansion of wind resource characterization to include Class 3 wind

- Modifications to the transportation module to allow the user to specify light-duty vehicle attributes over time for each vehicle type and class

- Minor modifications to the residential, commercial, industrial and transportation modules that allow easier implementation of EERE program assumptions.

\footnotetext{
${ }^{16}$ This section draws from the FY2010 detailed budget justification as described in U.S. DOE (2009). "FY2010 Congressional Budget Request Volume 3: Energy Efficiency and Renewable Energy, Electricity Delivery and Energy Reliability, Energy Transformation Acceleration Fund, Nuclear Energy." U.S. DOE, Office of the Chief Financial Officer, DOE/CF-037, http://www.cfo.doe.gov/budget/10budget/Content/Volumes/Volume3.pdf ${ }^{17}$ The analysis period has been extended to 2035 in AEO 2010.

${ }^{18}$ MARKAL, a model developed by the International Energy Agency, is tailored to support DOE's GPRA analysis of energy technology development beyond the time horizon of the AEO.

${ }^{19}$ The fraction of eligible buildings for PV systems was increased from 30 percent in the AEO 2008 reference case to 55 percent for commercial buildings and 60 percent for residential buildings in NEMS-EERE. In addition, PVs are allowed to compete in multi-family as well as single family buildings in the NEMS-EERE analysis. The California PV subsidy was also represented.
} 
The NEMS-EERE model provides the framework for the following GPRA FY2010 basic scenarios:

- Business-As-Usual (BAU) Baseline: Any identifiable future effects of the EERE portfolio are removed from the AEO 2008 Reference Case, and RE/EE technologies reflect only improvements anticipated by EERE in the absence of continued EERE program activities (which in some cases are more optimistic than EIA's assumptions). All other assumptions, including fossil and nuclear technology assumptions, are the same as those in the EIA AEO 2008 Reference Case. The GPRA BAU Baseline and the AEO 2008 Reference Case are both intended to represent only those policies that have been enacted into law, not possible future policies.

- Program Portfolio: NEMS-EERE is modified to estimate expected future program effects integrated across all EERE programs. This includes both modification of technology cost and performance assumptions in NEMS-EERE to reflect achievement of program goals and incorporation of external results related to specific technologies from more-detailed models. All other assumptions are the same as the BAU baseline. In this integrated scenario, individual EERE program technologies compete with each other to meet market demand.

- Individual Programs: Projected effects of individual EERE programs are represented in the absence of other programs.

These scenarios and the program-specific assumptions are described in more detail in EERE's forthcoming documentation of the GPRA FY2010 benefits analysis.

The GPRA benefits analysis requires that overall program goals be quantified as specific improvements. For example, the EERE program impacts on technology cost reduction, technology performance improvements, deployment barrier reduction or removal, or other improvements must be quantitatively expressed. These effects are associated with the proposed budget level. Overall, the benefits analysis quantifies the expected result of the public investment. If EERE programs are funded at the proposed budget level and achieve their stated cost, performance, and energy reduction goals, then they are expected to result in technology and system improvements (reflected in the program assumptions) that will create future economic, environmental, and energy security benefits (as quantified).

EERE programs are intended to change energy technologies and markets, and for this reason, their goals may involve substantial changes from business-as-usual conditions. The program assumptions involve the advancement of technologies and accelerated adoption rates for energy efficiency in all energy demand sectors and for renewable energy used primarily for power and liquid fuels substitution. 
All EERE programs except the relatively new Hydropower portion of the Wind and Hydropower Technologies Program were modeled for the FY2010 budget analysis:

- Biomass Program

- Building Technologies Program

- Federal Energy Management Program (FEMP)

- Fuel Cells Technologies Program

- Geothermal Technologies Program

- Hydrogen, Fuel Cells and Infrastructure Technologies Program

- Industrial Technologies Program

- Solar Energy Technologies Program

- Vehicle Technologies Program

- Weatherization and Intergovernmental Program (WIP)

- Wind and Hydropower Technologies Program

With an integrated model such as NEMS-EERE, interaction among programs and with the rest of the energy system can be considered. For example, increased energy efficiency and lower energy consumption lead to lower energy prices, which in turn can lead to a loss of some of the energy savings through either "rebound effects" (such as consumers raising thermostats) or lower market share for high efficiency technologies. At the same time, individual programs may compete with or be synergistic with other programs in the portfolio. Several programs seek to improve efficiency, which will reduce electricity demand and lead to reduced need for new generation capacity, while other programs aim to improve renewable generation technologies and increase their deployment. As a result, the net impact of the integrated EERE portfolio is not equal to the sum of the individual program impacts.

A summary of the major program activities and primary modeling methodology for each of the programs is shown in Table 1. For some programs, off-line analysis (i.e., analysis outside NEMS-EERE) is necessary either because the model lacks the technological detail to adequately represent the program $R \& D$ and deployment activities or because the program goals are based on historical or other criteria not found in NEMS-EERE. Specialized off-line tools can range from tools that estimate market share to those that perform an initial calculation of energy savings, depending on the treatment of the target market in NEMSEERE and on the nature of the program. 
Table 1. Modeling Methodology for Each EERE Program*

\begin{tabular}{|c|c|c|c|}
\hline EERE Program & Activity Area & $\begin{array}{l}\text { Off-Line } \\
\text { Tool }\end{array}$ & $\begin{array}{l}\text { NEMS- } \\
\text { EERE }\end{array}$ \\
\hline \multicolumn{4}{|c|}{ Programs Focused on Energy Efficiency } \\
\hline \multirow[t]{3}{*}{ Building Technologies } & Market enhancement & $\checkmark$ & \\
\hline & Regulatory actions & $\checkmark$ & \\
\hline & Technology RD\&D & $\checkmark$ & $\checkmark$ \\
\hline FEMP & Federal energy management & $\checkmark$ & \\
\hline \multirow{3}{*}{$\begin{array}{l}\text { Fuel Cells } \\
\text { Technologies }\end{array}$} & Fuel cells for $\mathrm{CHP}^{* *}$ and vehicles & & $\checkmark$ \\
\hline & Fuel cells for niche applications & $\checkmark$ & \\
\hline & Hydrogen production and delivery & & $\checkmark$ \\
\hline Industrial Technologies & Industrial programs & $\checkmark$ & \\
\hline \multirow[t]{2}{*}{ WIP } & Weatherization & $\checkmark$ & \\
\hline & Domestic intergovernmental activities & $\checkmark$ & \\
\hline \multicolumn{4}{|c|}{ Programs Focused on Renewable Energy } \\
\hline Biomass & Cellulosic ethanol & & $\checkmark$ \\
\hline $\begin{array}{l}\text { Geothermal } \\
\text { Technologies }\end{array}$ & $\begin{array}{l}\text { Hydrothermal power and enhanced geothermal systems } \\
\text { (EGS) }\end{array}$ & & $\checkmark$ \\
\hline \multirow{2}{*}{$\begin{array}{l}\text { Solar Energy } \\
\text { Technologies }\end{array}$} & Photovoltaic systems & & $\checkmark$ \\
\hline & Concentrated solar power & & $\checkmark$ \\
\hline \multirow[t]{3}{*}{ Vehicle Technologies } & $\begin{array}{l}\text { Light-duty vehicles (LDVs): Diesel vehicles, hybrid vehicles, } \\
\text { and plug-in hybrid electric vehicles (PHEVs) }\end{array}$ & & $\checkmark$ \\
\hline & Light-weight materials for LDVs & & $\checkmark$ \\
\hline & Heavy-duty vehicles & $\checkmark$ & $\checkmark$ \\
\hline $\begin{array}{l}\text { Wind and Hydropower } \\
\text { Technologies }\end{array}$ & Wind & & $\checkmark$ \\
\hline
\end{tabular}

\section{EERE Programs Focused on Energy Efficiency}

For each of the programs that is generally focused on energy efficiency (buildings, industry, vehicle, FEMP, and WIP), we describe its objectives and the method we used to represent the program in NEMS-EERE. The Buildings, Industrial, and Vehicle Technologies programs are primarily involved in developing and increasing deployment of technologies that lead to greater energy efficiency, reduced environmental impact, and reduced petroleum use. FEMP facilitates implementation of efficiency and renewable energy technologies in federal facilities and equipment as part of its overall support for federal leadership in energy management and cost-effective energy investment. WIP's mission is to accelerate deployment of energy efficiency, renewable energy, and oil displacement technologies, with a focus on activities of nonfederal government jurisdictions as well as other stakeholders.

The Building Technologies program is represented in the model by a combination of specific technology improvements (such as cost and efficacy of solid-state lighting) and off-line estimates of energy savings from more detailed modeling (such as for commercial shell 
efficiency improvements), while the Industrial Technologies Program analysis is performed outside of NEMS-EERE.

FEMP and WIP estimates are based on historical data linking EERE budgets to energy savings and so are also estimated outside of NEMS-EERE. The off-line analyses provide energy savings that are used as inputs to NEMS-EERE.

Figure 1 illustrates the energy savings for each of the energy efficiency programs when analyzed individually in a business-as-usual scenario. These savings are slightly different when combined, as they are under the EERE Base Case (due to interactive effects across the portfolio) or EERE S. 2191 Case (due to interaction between the policy and the technology improvements).

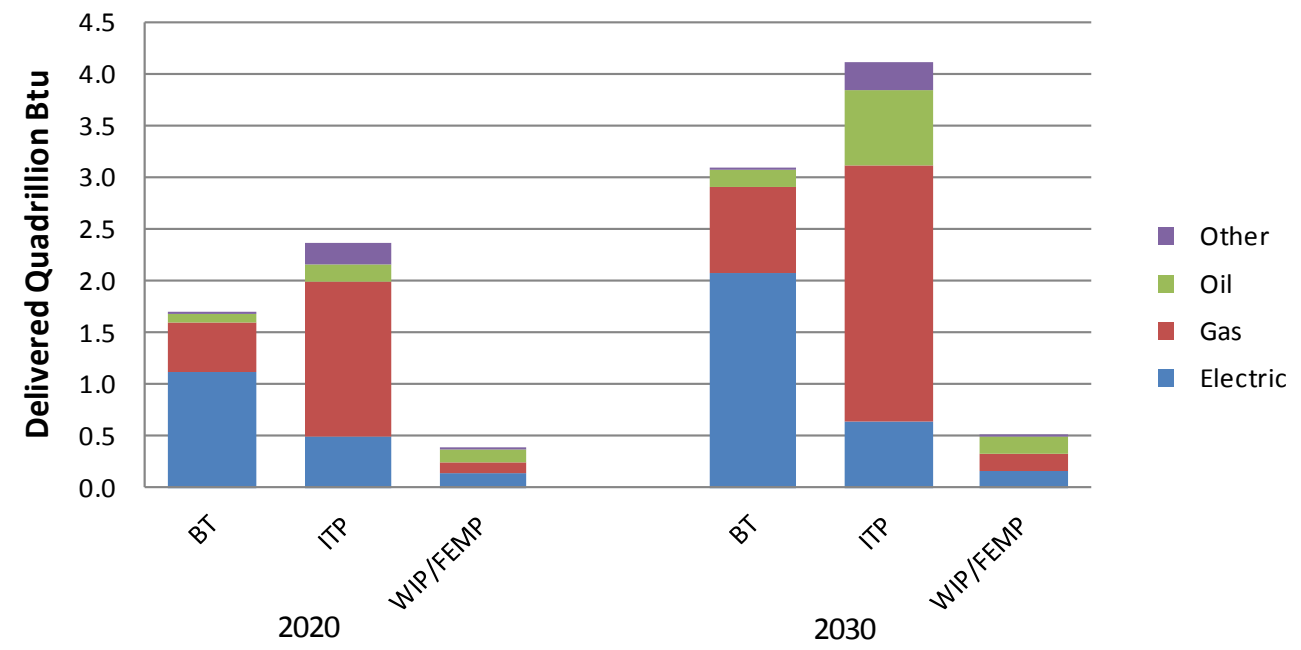

Figure 1. Energy reductions by program

BT = Building Technologies Program;

ITP = Industrial Technologies Program

The Vehicle Technologies Program, on the other hand, is modeled primarily by representing improvements to vehicle characteristics. For light-duty vehicles, the cost, fuel economy, and performance attributes are provided by advanced vehicle type (e.g., advanced diesels, hybrids, and plug-in hybrids) for each of six size classes for both cars and light trucks (see Table 2 for a sample of the vehicle price and fuel economy assumptions for two size classes). ${ }^{20}$ In addition, consumer biases against advanced vehicles are assumed to be mitigated by the program's activities. The model is then used to project the adoption (sales) of the various technologies in the market for light-duty vehicles over time, the stock of these vehicles and the vehicle miles traveled associated with each technology. For heavy trucks, the market adoption of advanced vehicles is estimated off-line and used as an input to NEMS-EERE for the stock accounting and energy savings estimates.

\footnotetext{
${ }^{20}$ Conventional vehicles are less efficient in the EERE case due to greater adoption of advanced vehicle technology, which alleviates the need for conventional technology improvements in meeting Corporate Average Fuel Economy standards.
} 
The Fuel Cells Technologies Program seeks to advance fuel cell technologies through research, development, and demonstration, in order to achieve cost and functional competitiveness. The attributes of hydrogen fuel cell, light-duty vehicles are modified within NEMS-EERE — similarly to the method used for the Vehicles Technologies Program - to represent the program's RD\&D efforts.

Table 2. Comparison of NEMS-EERE and EIA Vehicle Assumptions in 2030

\begin{tabular}{lcccc}
\hline & \multicolumn{2}{c}{ Midsize Cars } & \multicolumn{2}{c}{ Large SUVs } \\
& EIA & $\begin{array}{c}\text { NEMS- } \\
\text { EERE }\end{array}$ & EIA & $\begin{array}{c}\text { NEMS- } \\
\text { EERE }\end{array}$ \\
\hline Fuel Economy (miles per gallon) & & & \\
Gasoline & 39.4 & 35.0 & 26.9 & 25.7 \\
Ethanol-Flex & 40.0 & 35.3 & 27.2 & 26.0 \\
Diesel & 50.2 & 49.9 & 34.3 & 35.1 \\
Gasoline-Electric Hybrid & 53.0 & 72.2 & 35.0 & 46.6 \\
Diesel-Electric Hybrid & 56.8 & 79.9 & 40.9 & 51.9 \\
Plug-in Gasoline Hybrid & 72.0 & 96.7 & 50.3 & 60.2 \\
Fuel Cell Hydrogen & 54.1 & 104.0 & 34.3 & 66.9 \\
Plug-in Fuel Cell & $\mathrm{n} / \mathrm{a}$ & 130.7 & $\mathrm{n} / \mathrm{a}$ & 84.7 \\
Vehicle Prices (thousand $2006 \$$ ) & & & \\
Gasoline & 26.4 & 25.5 & 37.0 & 36.8 \\
Ethanol-Flex & 26.7 & 25.9 & 37.4 & 37.1 \\
Diesel & 27.6 & 28.8 & 38.3 & 39.2 \\
Gasoline-Electric Hybrid & 28.0 & 29.0 & 40.1 & 40.5 \\
Diesel-Electric Hybrid & 32.6 & 30.0 & 45.8 & 41.2 \\
Plug-in Gasoline Hybrid & 32.2 & 28.7 & 45.2 & 40.2 \\
Fuel Cell Hydrogen & 51.5 & 28.6 & 72.9 & 41.0 \\
Plug-in Fuel Cell & $\mathrm{n} / \mathrm{a}$ & 28.8 & $\mathrm{n} / \mathrm{a}$ & 41.8 \\
\hline
\end{tabular}

\section{EERE Programs Focused on Renewable Sources for Fuels and Electricity Generation}

The programs that focus on fuels and electricity generation are described here in terms of their objectives and representation of resource and technology in the model. The Biomass Technologies Program seeks to facilitate development of biofuels, bioproducts, and biopower. It is modeled in NEMS-EERE for the benefits analysis through the improvement of cellulosic ethanol production characteristics - lower costs and higher yields. 
As shown in Figure 2, our analysis uses a more optimistic assumption about improvements in cellulosic technology even without future DOE RD\&D than EIA does in the updated AEO 2008 Reference Case. The private sector is assumed to continue biofuels research but at a slower pace without DOE participation; over the long-term, it is assumed to achieve similar cost reductions and improved yields.

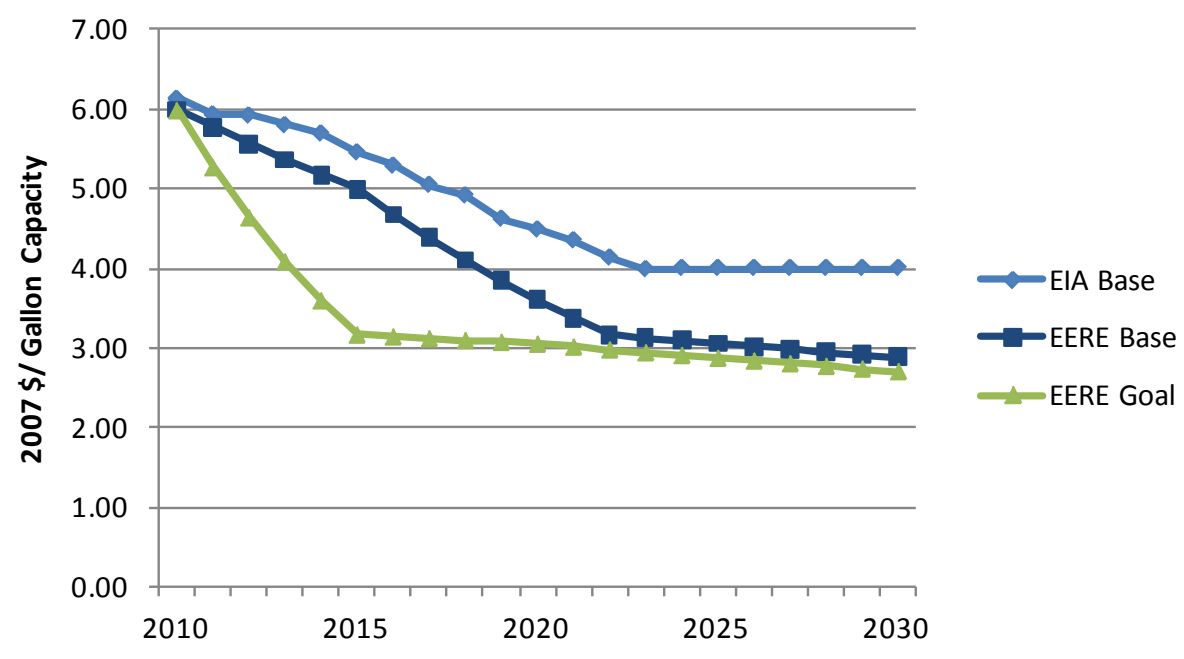

Figure 2. Cellulosic ethanol investment cost

The geothermal, solar, and wind power programs conduct RD\&D to accelerate commercialization of renewable generation technologies. The Geothermal Technologies Program focuses on EGS. The Solar Technologies Program focuses on electricity generation but includes solar heating activities not analyzed in the GPRA benefits analysis. The wind portion of the Wind and Hydropower Technologies Program emphasizes development and deployment along with low wind-speed turbine improvements. The hydropower portion includes both marine and hydrokinetic technologies. The RD\&D goals for each of these programs are represented within NEMS-EERE by improvements in capital costs and capacity factors for these technologies. Geothermal, concentrated solar and wind technologies are primarily large, centralized generation technologies and compete with conventional, advanced fossil and nuclear technologies for market share. 
NEMS-EERE is able to characterize the regional variability of renewable resources and therefore the attractiveness of these technologies in the model's 13 NERC regions and subregions. We include updates to the geothermal resource to reflect new information about hydrothermal resources and EGS. ${ }^{21}$ Solar photovoltaic (PV) systems are represented as utility scale as well as distributed generation where homes or businesses evaluate the costeffectiveness of installing PV systems to reduce their purchases of electricity. The costs used in the model of a sample of renewable generation technologies and their operating characteristics are shown in Table 3.

For comparison, Table 4 illustrates the costs of select fossil generation options, including advanced nuclear, integrated gasification combined cycle (IGCC) coal with and without CCS technology, advanced gas combined cycle, and IGCC biomass technologies. Although power plant costs have escalated in recent years, the values shown in Table 3 and Table 4 are designed to be consistent between technologies and therefore are not unduly biased by these cost escalations. However, higher power plant costs, such as EIA's more recent estimates in the AEO2010 Reference Case, would penalize all capital intensive technologies (such as coal, nuclear, and most renewables) and would also likely increase the overall cost of meeting caps in $\mathrm{CO}_{2}$ emissions.

\footnotetext{
${ }^{21}$ Petty, S.; Porro, G. (2007). Updated U.S. Geothermal Supply Characterization. 24 pp.; NREL Report No. CP-
} 640-41073. 
Table 3. Comparison of NEMS-EERE and EIA Renewable Generation Technology Assumptions*

\begin{tabular}{|c|c|c|c|c|c|c|c|c|c|c|}
\hline & \multicolumn{2}{|c|}{$\begin{array}{c}\text { Class } 4 \\
\text { Onshore Wind }\end{array}$} & \multicolumn{2}{|c|}{$\begin{array}{c}\text { Class } 6 \\
\text { Onshore Wind }\end{array}$} & \multicolumn{2}{|c|}{$\begin{array}{c}\text { Class } 6 \\
\text { Offshore Wind }\end{array}$} & \multicolumn{2}{|c|}{$\begin{array}{c}\text { Concentrated } \\
\text { Solar Power }\end{array}$} & \multicolumn{2}{|c|}{ Residential PV } \\
\hline & EIA & NEMS-EERE & EIA & NEMS-EERE & EIA & NEMS-EERE & EIA & NEMS-EERE & EIA & NEMS-EERE \\
\hline \multicolumn{11}{|c|}{ Overnight Capital Costs $(2006 \$ / k W)^{\star *}$} \\
\hline 2010 & 1423 & 1422 & 1423 & 1422 & $\mathrm{n} / \mathrm{a}$ & 2812 & 3379 & 4803 & 6165 & 5027 \\
\hline 2015 & 1415 & 1193 & 1415 & 1300 & 2741 & 1984 & 3122 & 4159 & 5477 & 3317 \\
\hline 2020 & 1411 & 1100 & 1411 & 1225 & 2658 & 1700 & 2846 & 3836 & 4773 & 2819 \\
\hline 2025 & 1407 & 1048 & 1407 & 1136 & 2574 & 1600 & 2638 & 3478 & 4367 & 2396 \\
\hline 2030 & 1403 & 1016 & 1403 & 1118 & 2490 & 1468 & 2430 & 3037 & 3961 & 2037 \\
\hline \multicolumn{11}{|c|}{ Capacity Factors } \\
\hline 2010 & 0.31 & 0.39 & 0.39 & 0.46 & 0.39 & 0.41 & 0.38 & 0.41 & \multirow{5}{*}{\multicolumn{2}{|c|}{$\begin{array}{c}\text { varies by region } \\
\text { same in both }\end{array}$}} \\
\hline 2015 & 0.32 & 0.44 & 0.40 & 0.48 & 0.40 & 0.53 & 0.39 & 0.41 & & \\
\hline 2020 & 0.33 & 0.45 & 0.41 & 0.49 & 0.41 & 0.53 & 0.39 & 0.68 & & \\
\hline 2025 & 0.33 & 0.45 & 0.41 & 0.49 & 0.42 & 0.53 & 0.39 & 0.74 & & \\
\hline 2030 & 0.34 & 0.45 & 0.42 & 0.49 & 0.43 & 0.53 & 0.38 & 0.79 & & \\
\hline
\end{tabular}

*Only a sample of wind classes and PV systems is shown here for illustrative purposes. Geothermal is not shown due to its highly site specific characteristics in NEMS.

** Overnight capital costs do not include transmission costs, interest during construction, or investment tax credits. 
Table 4. EIA Fossil Generation Technology Assumptions

\begin{tabular}{cccccc}
\hline & $\begin{array}{c}\text { Advanced } \\
\text { Nuclear }\end{array}$ & $\begin{array}{c}\text { IGCC } \\
\text { with CCS }\end{array}$ & $\begin{array}{c}\text { IGCC } \\
\text { without CCS }\end{array}$ & $\begin{array}{c}\text { Advanced Gas Combined } \\
\text { Cycle }\end{array}$ & $\begin{array}{c}\text { IGCC } \\
\text { Biomass }\end{array}$ \\
\hline \multicolumn{2}{l}{ Overnight Capital Costs (2006\$/kW)* } & & & & \\
2010 & $\mathrm{n} / \mathrm{a}$ & $\mathrm{n} / \mathrm{a}$ & $\mathrm{n} / \mathrm{a}$ & 702 & $\mathrm{n} / \mathrm{a}$ \\
2015 & $\mathrm{n} / \mathrm{a}$ & 2,428 & 1,723 & 690 & 2,695 \\
2020 & 2,310 & 2,347 & 1,684 & 677 & 2,610 \\
2025 & 2,241 & 2,266 & 1,646 & 664 & 2,525 \\
2030 & 2,172 & 2,185 & 1,607 & 651 & 2,439 \\
\hline
\end{tabular}

* Overnight capital costs do not include transmission costs or interest during construction. Also excludes effect of any investment tax credits. 


\section{Modeling Scenarios}

To examine the potential impact of EERE programs if S. 2191 were enacted, we ran two new scenarios:

- EERE Base Case: AEO 2008 Reference Case with EERE program goals achieved and no $\mathrm{CO}_{2}$ cap-and-trade policy, using the NEMS-EERE integrated model. This case is equivalent to the EERE GPRA FY2010 Program Portfolio Case.

- EERE S. 2191 Case: S. $2191 \mathrm{CO}_{2}$ cap-and-trade policy case with EERE program goals achieved.

We compared these results to the EIA S. 2191 scenarios:

- EIA Base Case: AEO 2008 Reference Case developed by the EIA, representing a business-as-usual scenario without EERE program goals

- EIA S. 2191 Case: S. $2191 \mathrm{CO}_{2}$ cap-and-trade core policy case without EERE programs. Although EIA ran sensitivity cases to test key assumptions in the core policy case, these will not be discussed in this paper.

We will focus on the differences between the EERE S. 2191 Case and the EIA Base and S. 2191 Cases as a means to explore the ability of EERE programs to help meet the requirements of the $\mathrm{CO}_{2}$ cap in a cost-effective way. These differences will include the effects of both the EERE programs and the price response related to the cap-and-trade policy. In most cases, we will not attempt to isolate the program effect from the policy effect when discussing the results of the analysis.

EIA used an updated AEO 2008 version of NEMS for its original analysis of S. 2191. We recreated the EIA S. 2191 scenarios using the NEMS-EERE model described here (but without the modifications made to represent EERE programs as described in Section 4), which was created for use in analyzing the EERE FY2010 programs. Use of the NEMS-EERE model for all four scenarios ensures that all results are comparable. However, the results of the EIA S. 2191 scenarios presented in Section 5 may differ slightly from EIA's published results. 


\section{Results}

\section{$\mathrm{CO}_{2}$ Allowance Prices and Emissions}

Figure 3 compares annual covered greenhouse gas emissions for each of the four scenarios (two of which have identical emissions - the S. 2191 Cases), and it displays the S. 2191 cap level, which is not one of the scenario emission levels. The EERE Base Case without a $\mathrm{CO}_{2}$ cap-and-trade policy reduces covered emissions by 14 percent by 2030 relative to EIA's Base Case. The S. 2191 Case with EERE programs has essentially the same covered emissions as the S.2191 Case without EERE programs, due to the cap. There are a few minor differences in annual banking of allowances between these two S. 2191 cases, but emissions from both appear as a single line in Figure 3. The S. 2191 Cases reduce emissions about 55 percent from the EIA Base Case by 2030 in order to meet the bill's requirements. Emission reductions include offset credits that can be used in place of allowances to meet the requirement up to the bill's specified offset limit of 30 percent of the emissions cap.

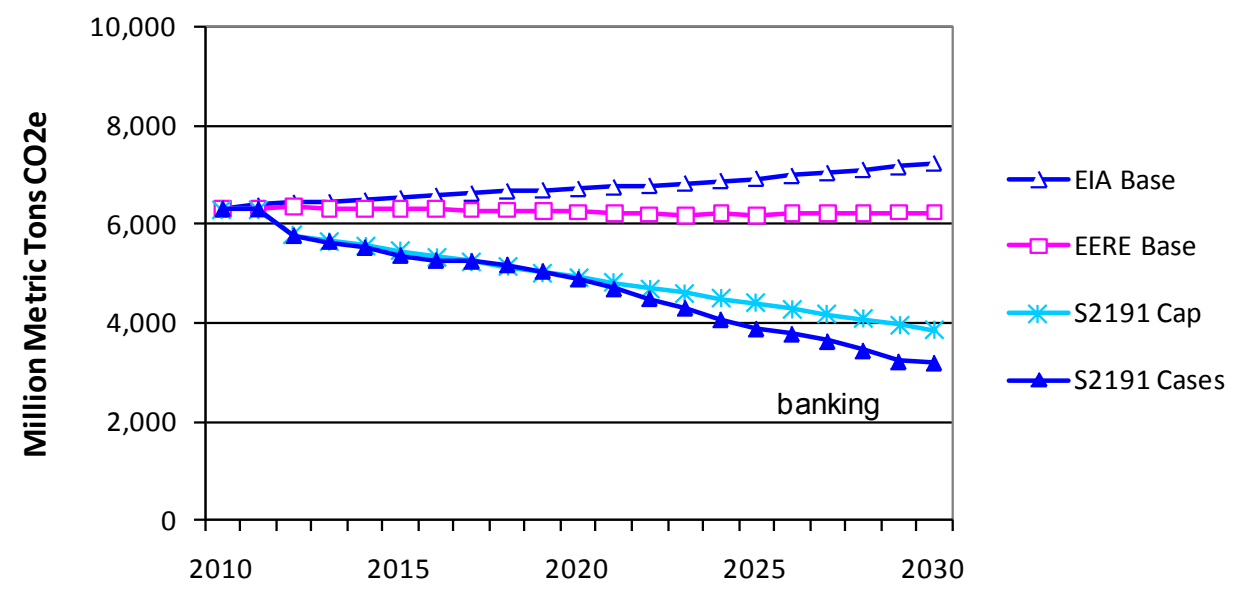

Figure 3. Covered greenhouse gas emissions less offsets

Banking is measured as the difference between the emissions cap and the actual covered emissions for the Core Cases as shown in Figure 3. Banking allows covered sources to set aside excess allowances and offsets for use in meeting requirements in future years. In the S. 2191 Cases, emitters are projected to bank excess emission allowances starting in 2019 in order to build a cumulative bank of 5 billion allowances by 2030 for use in years beyond 2030 when the bill's requirements become more stringent. EIA chose the 2030 cumulative bank target for its S. 2191 analysis; for consistency, we used the same target in the EERE S. 2191 Case. These banking assumptions can have a significant impact on the cost of the policy by changing the total cumulative emissions reductions required by 2030 . In our analysis, a 2030 bank balance of 5 billion allowances adds about 13 percent to the required emissions reductions in both S. 2191 Cases. To explain their choice of 5 billion allowances, EIA states "This level of allowance banking is consistent with the greater difficulty complying with the 
post-2030 targets under continued growth in population and the economy, yet balanced by the technological progress likely to help mitigate the economic cost of abatement.",22

Figure 4 illustrates that if EERE program benefits are realized, $\mathrm{CO}_{2}$ allowance prices required to meet future S. 2191 policy goals are projected to be about $\$ 41$ per ton by 2030 (measured in real 2006 dollars) or about 34 percent lower than the EIA projected allowance price of $\$ 62$ per ton. $^{23}$

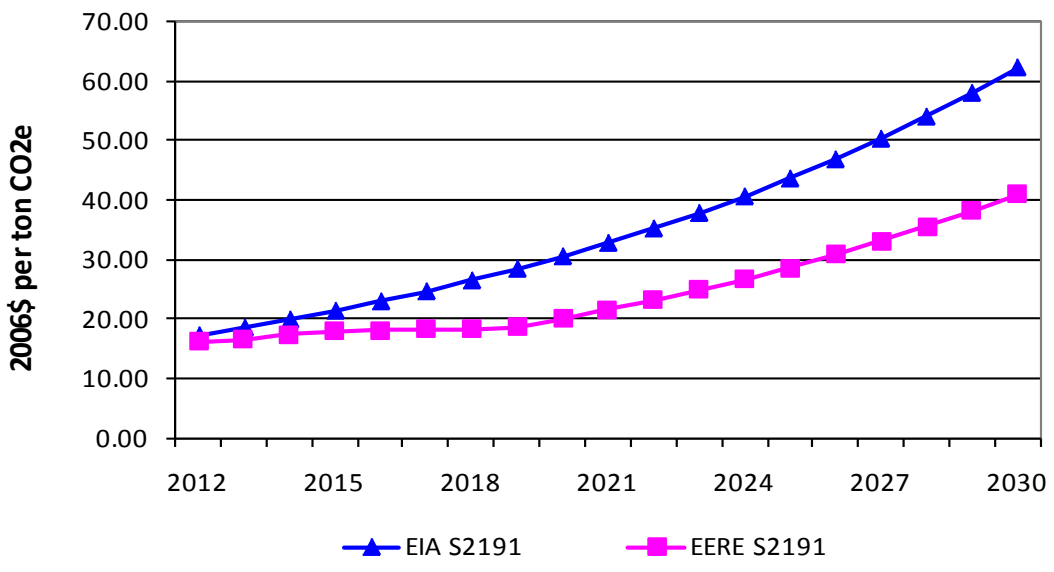

Figure 4. $\mathrm{CO}_{2}$ allowance prices

Lower allowance prices generally translate into lower energy prices for consumers because energy producers can usually include some or all of their allowance costs in the price of their products. The NEMS scenarios assume full cost recovery in all non-electric energy markets and partial recovery in electricity markets due to competitive, marginal cost pricing in some regions.

Figure 5 compares a sample of national average, delivered energy prices in the S. 2191 Cases compared with prices in the EIA Base Case in 2030. The allowance price is evident in all of these prices, but the magnitude of the allowance price effect varies, depending upon the carbon content of the fuel and the ability of producers to recover costs. Coal prices (with carbon cost included) rise the most in a carbon-constrained scenario, increasing from almost $\$ 2$ per million Btu (mmBtu) in the base case to more than \$7 per mmBtu in the EIA S. 2191 Case, which is more than triple the base case forecasted price. Because the EERE S. 2191 Case results in lower allowance prices, coal prices are much lower than in the EIA S. 2191 Case but still more than double the base case price by 2030. In addition, the EERE programs result in lower demand and provide improved technologies that lead to lower energy prices. The impact on gasoline prices is less severe due to the fuel's lower carbon content: the EIA

\footnotetext{
22 "Energy Market and Economic Impacts of S. 2191, the Lieberman-Warner Climate Security Act of 2007," Energy Information Administration Office of Integrated Analysis and Forecasting, SR/OIAF/2008-01, April 2008 , page 7 .

${ }^{23}$ As described in Section 2, the EIA S. 2191 allowance prices are assumed to increase at 7.4 percent per year in real terms. The EERE case adopts the same growth rate beginning in 2019 when banking starts. Prior to 2019, there is insufficient incentive for banking in this case so the model determines the allowance price needed to meet the annual emissions cap without banking.
} 
S. 2191 Case is 18 percent or roughly $\$ 0.45$ per gallon higher than the base price whereas the EERE S. 2191 Case is only 6 percent higher than the base case in 2030.

Electricity prices are affected less by allowance prices for a number of reasons: the mix of fuels used to generate electricity (and their carbon content) changes over time; free allowance allocations to electric generators and electric load-serving entities provide some rate relief, especially in the early years; and competitive pricing in some regions reduces the allowance price impact. ${ }^{24}$ Average electricity prices under a carbon scenario are about 11 percent or 1.0 cents per kWh higher comparing EIA S. 2191 to EIA Base Case in 2030 and about 3 percent higher comparing EERE S. 2191 to EIA Base Case.

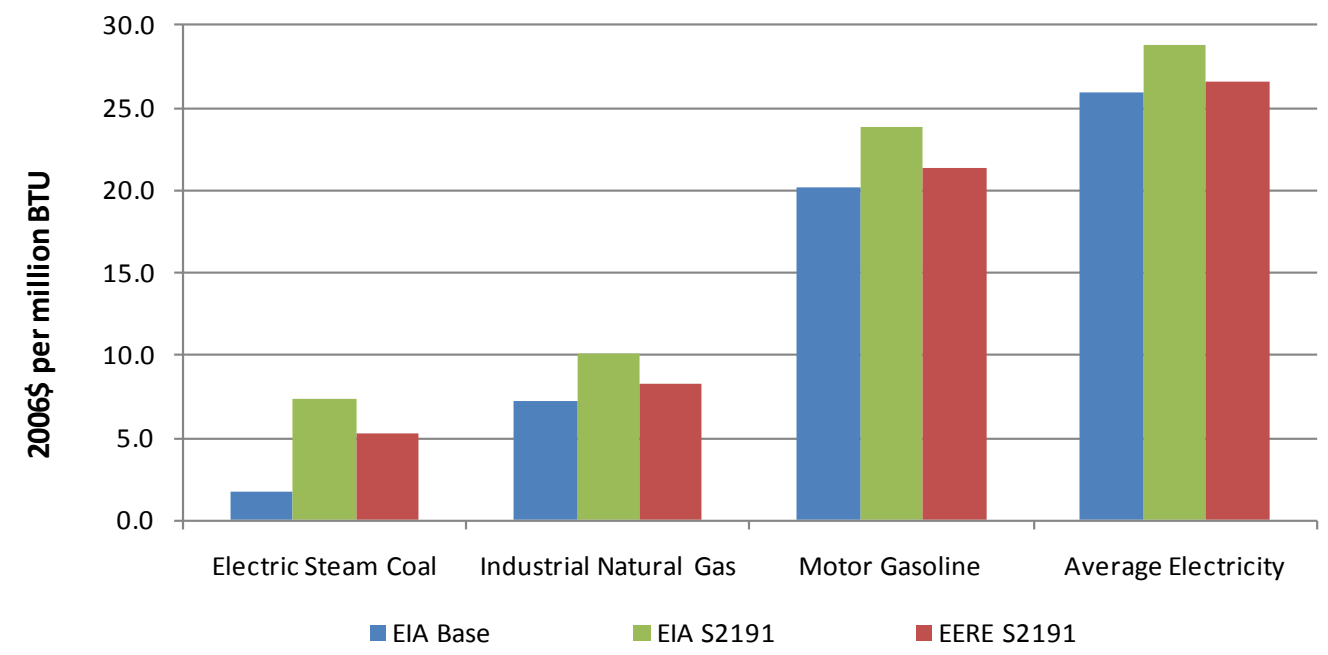

Figure 5. Delivered energy prices in 2030

\section{Sectoral Results}

As shown in Figure 6, the electric power sector is projected to reduce the largest sectoral share of energy-related emissions in both climate policy scenarios. Reductions are calculated from the EIA Base Case in order to illustrate the combined effect of the EERE programs and the climate policy in reducing emissions in the EERE S. 2191 Case. Between 80 percent and 90 percent of total reductions by 2030 are related to electricity and are due to a combination of fuel switching to low-carbon sources of electricity and energy efficiency improvements by the end-use sectors. Because the electric power industry depends heavily on carbon-rich coal and is the primary consumer of coal in the United States, it is able to reduce emissions substantially by switching from coal to other fuels through a combination of plant dispatch and capacity investment decisions. These scenarios assume that low-carbon options such as nuclear and CCS are cost-effective and are available for fuel switching; if these options are not available or are more expensive, emission reductions from the electricity sector would be more limited and the price of carbon allowances would be higher. The residential, commercial, and industrial sectors contribute to electric sector reductions 1) by increasing

\footnotetext{
${ }^{24}$ The cases assume electricity prices are determined differently, depending on whether the regional market is a competitive market or a regulated one. In portions of the country with competitive markets, high-carbon electricity producers cannot pass full allowance costs on to consumers, whereas in parts of the country with regulated markets, producers are assumed to be allowed to recover average costs of service, including allowance costs. Whether this holds true is contingent on regulators' decisions.
} 
purchases of energy efficient electricity-using devices - many of which are enhanced by EERE programs - and 2) by reducing their demand for energy services. The transportation sector depends on carbon-rich petroleum products and currently has limited cost-effective options for fuel switching. However, the EERE Vehicle Technologies and Biomass Programs are working to expand transportation options for advanced vehicles and fuels. These results are based on the assumption that current regulations and consumer behavior do not change over time. However, future regulatory changes - such as stronger Corporate Average Fuel Economy (CAFE) standards for vehicles or enhanced appliance standards - or other changes that may significantly alter consumer attitudes toward energy use, may provide greater emissions reductions from sources other than electricity generation than these results illustrate.

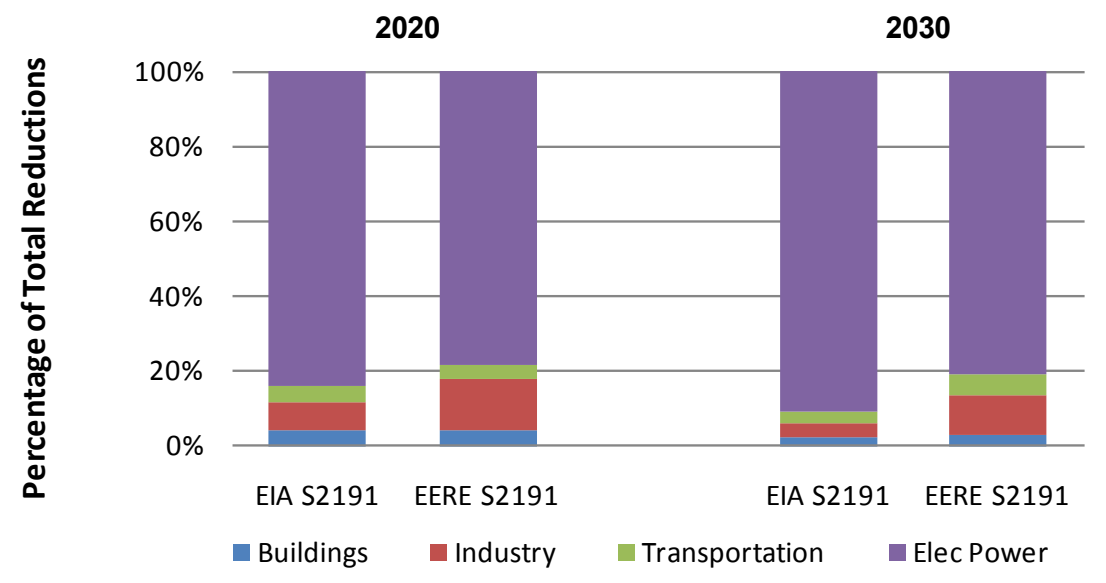

Figure 6. Energy-related $\mathrm{CO} 2$ emission reductions from EIA base;

End-use emissions are non-electric only; electricity-related reductions are included in the electric power sector.

Figure 7 illustrates each sector's share of emissions in 2030 in the EIA Base Case and in the EERE S. 2191 Case. Despite reductions from the EERE efficiency programs (buildings, FEMP, fuel cells, industry, and WIP), the share of total energy-related $\mathrm{CO}_{2}$ emissions from non-electric sectors increases from 57 percent in the EIA Base Case in 2030 to more than 80 percent in the EERE S. 2191 Case because of significant reductions from the electric power sector. The buildings and industry share of total emissions show a modest increase of 3 percent to 5 percent of total emissions by 2030, while transportation's share of emissions increases dramatically compared to the base case. Transportation-related emissions are projected to be half of total emissions in the S. 2191 Case compared to one-third in the EIA Base Case. Current shares of emissions are similar to the EIA Base Case 2030 emissions. 


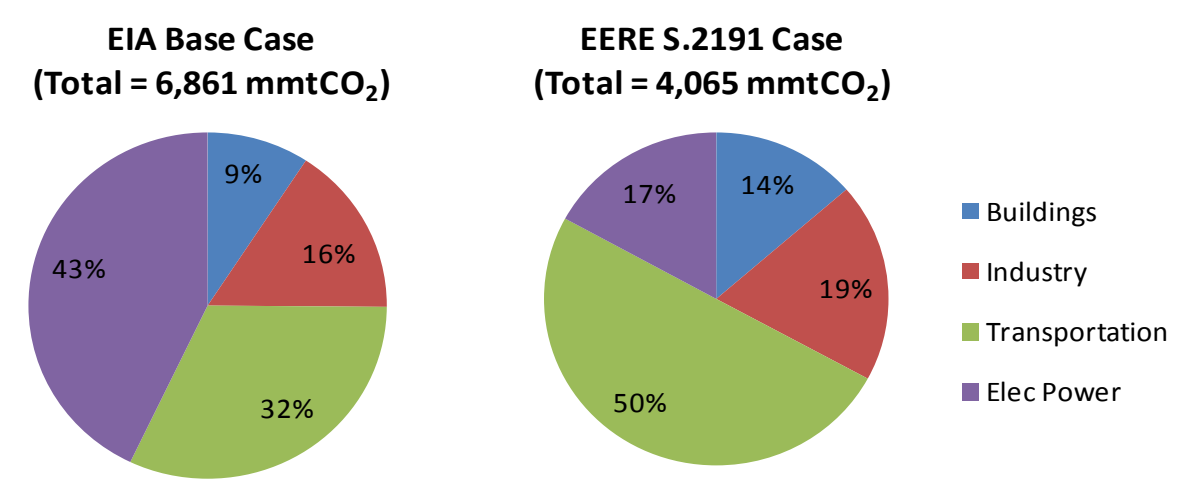

Figure 7. Energy-related $\mathrm{CO}_{2}$ emissions by end-use sector in $\mathbf{2 0 3 0}$

Economy-wide primary energy consumption by fuel tells a similar story, as shown in Figure 8. Liquid fuels are the dominant fuel source in the U.S. economy, especially in the transportation sector where about 70 percent of liquid fuels are currently consumed. Both of the S. 2191 Cases are projected to reduce fossil fuel consumption by about 30 percent by 2030 , with most of the reductions in coal and natural gas used in electricity generation. In the EIA S. 2191 Case, nuclear generation increases the most in response to fossil generation reductions, while in the EERE S. 2191 Case, demand reduction and renewable generation provide the corresponding increase. Much of the demand reduction occurs in the EERE Base Case without the climate policy, whereas the change in fuel mix from fossil fuels to renewable generation is primarily a function of the policy. Liquid fuels consumption in 2030 is reduced 5 percent in the EIA S. 2191 Case compared to the base case, and 8 percent in the EERE S. 2191 Case. These results may differ under different assumptions about relative costs of nuclear, energy efficiency, and renewable generation technologies.

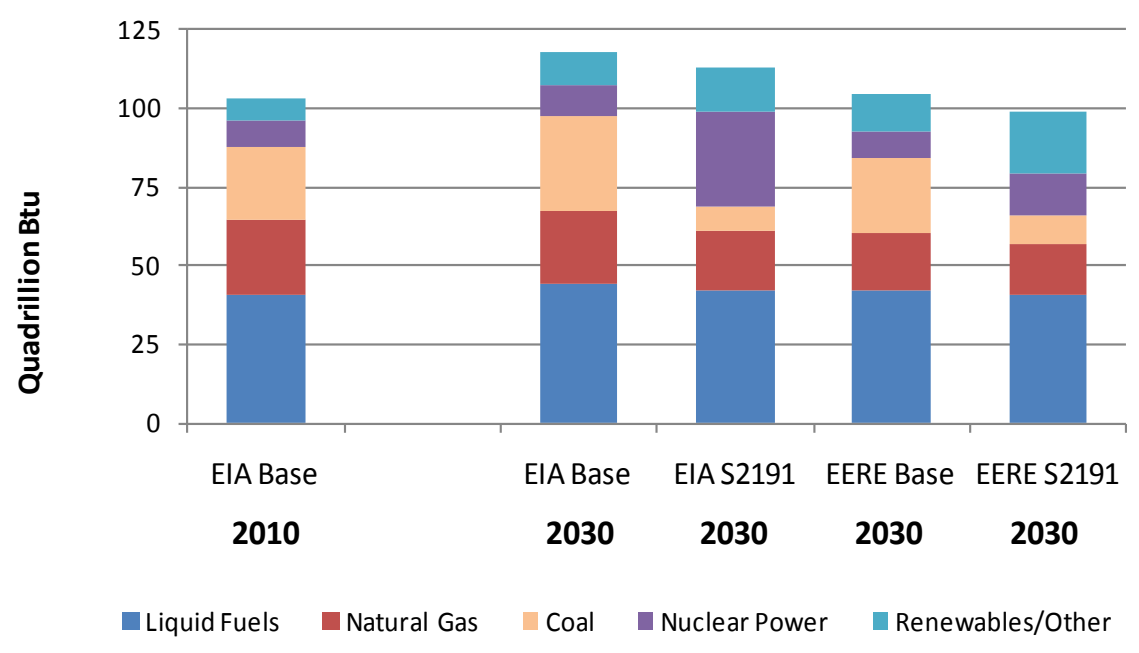

Figure 8. Primary energy consumption by fuel 
The next two figures illustrate the change in delivered energy demand by sector between 2010 and 2030. In Figure 9, total delivered energy in 2010 is projected to be 75 quadrillion Btu (quads), of which about 20 quads will be consumed by the residential and commercial sectors, 26 quads by the industrial sector (including refineries), and 29 quads by the transportation sector. Delivered energy demand is projected to increase 10 quads or about 13 percent by 2030 in the EIA Base Case but only 5 quads or 7 percent in the EIA S. 2191 Case; it is expected to decrease 1.5 quads or 2 percent in the EERE S. 2191 Case. Shown a different way, Figure 10 illustrates that EERE programs can dramatically reduce the projected growth in delivered energy demand over the next 20 years. Demand growth actually declines in the residential and industrial sectors and in total delivered energy demand in the EERE S. 2191 Case from 2010 levels, and growth is reduced significantly in the commercial and transportation sectors. This is greater than the changes in behavior and efficiency adoption that occur with carbon pricing alone in the EIA S. 2191 Case.

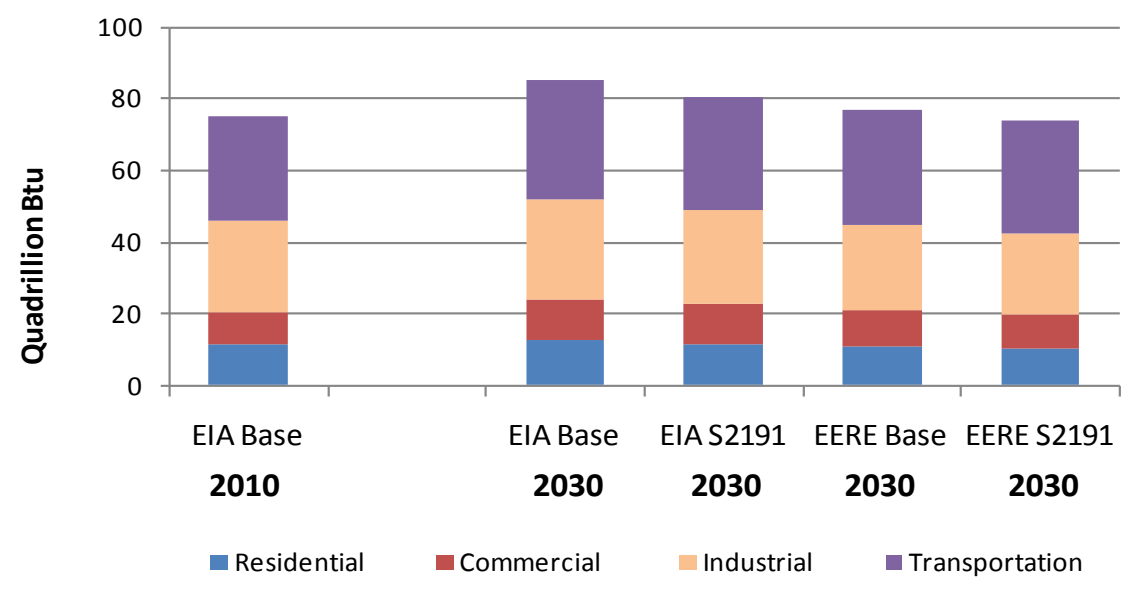

Figure 9. Delivered energy demand by sector

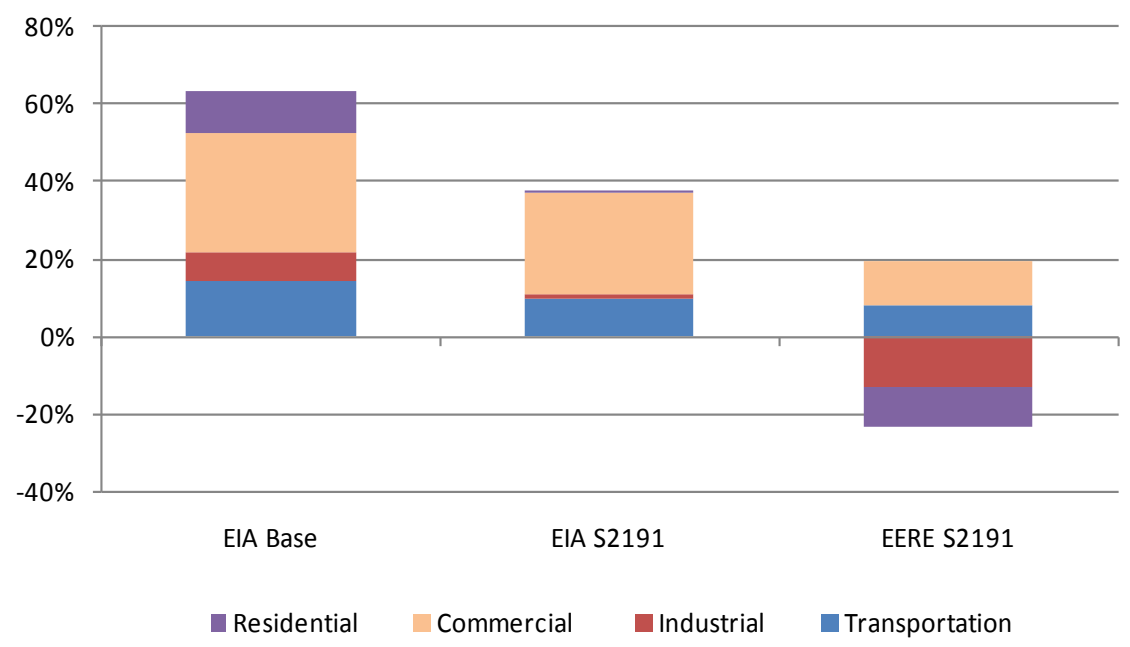

Figure 10. Growth in delivered energy demand in years 2010-2030 
The following discussion explores the sources of these sectoral emission reductions in more detail for the electric power sector, the buildings and industrial sectors, and the transportation sector.

\section{Electric Power Sector}

As shown in Figure 11, the EERE cases result in an average of 18 percent to 23 percent reduction in electricity sales by 2030 relative to the EIA Base Case, primarily due to EERE energy efficiency programs. Reductions related to the climate policy are about 5 percent of sales in both the EIA and EERE S. 2191 Cases compared to their respective base cases. Reductions in electricity sales result in reduced emissions from the electric power sector. Electricity demand from electric vehicles increased from 9 billion $\mathrm{kWh}$ in the EIA Base Case to 18 billion $\mathrm{kWh}$ in the EERE cases, but this represents less than one percent of total sales.

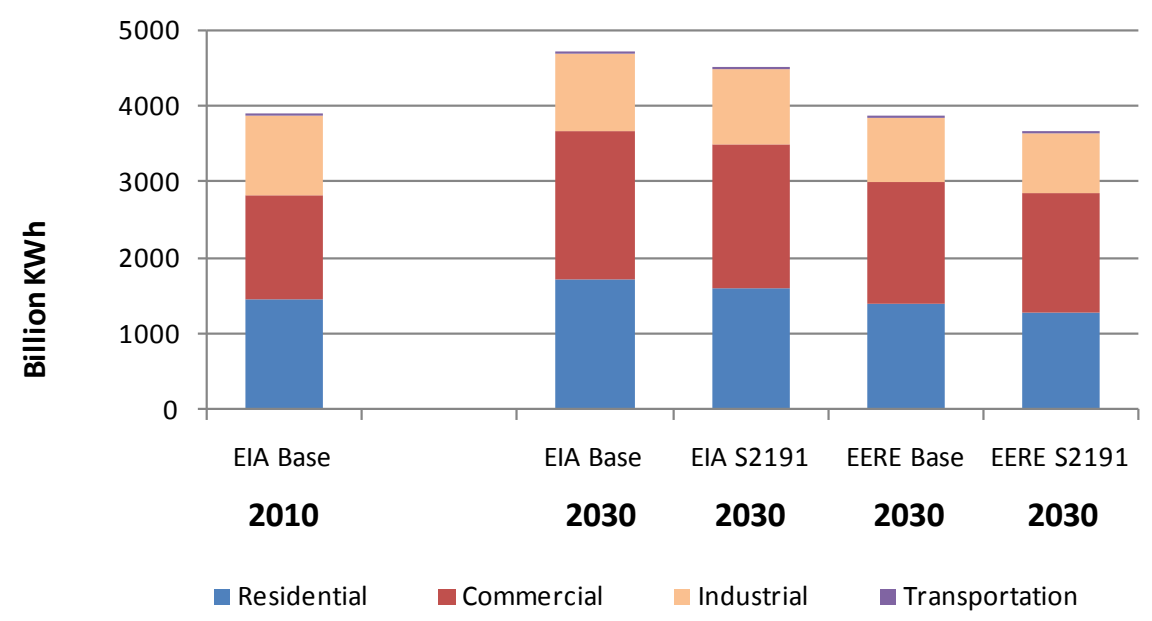

Figure 11. Electricity sales by sector in $\mathbf{2 0 3 0}$

Other emission reductions from the power sector come from fuel switching to low-carbon or non-carbon fuels such as renewable energy, both by changing investment decisions for new capacity and by changing the dispatch of existing plants. Figure 12 illustrates the capacity investment decisions that are projected to occur under a climate scenario with and without EERE RD\&D programs.

Conventional coal capacity is reduced more than 65 percent in both of the S. 2191 Cases compared to the EIA Base Case due to retirements, and other conventional fossil capacity such as natural gas is reduced more than 20 percent. These capacity changes are due to a combination of fewer fossil-fueled plants being built under a carbon scenario, and existing fossil capacity being retired, although some investment is made in new CCS technologies. Nuclear capacity increases dramatically in the EIA S. 2191 Case to reduce carbon emissions, with 270 gigawatts of new capacity built (or about 270 new plants), whereas the EERE S. 2191 Case builds a more modest 63 new nuclear plants by 2030. Renewable capacity increases in both S. 2191 Cases, but as expected, the increase is more dramatic in the EERE S. 2191 Case. 


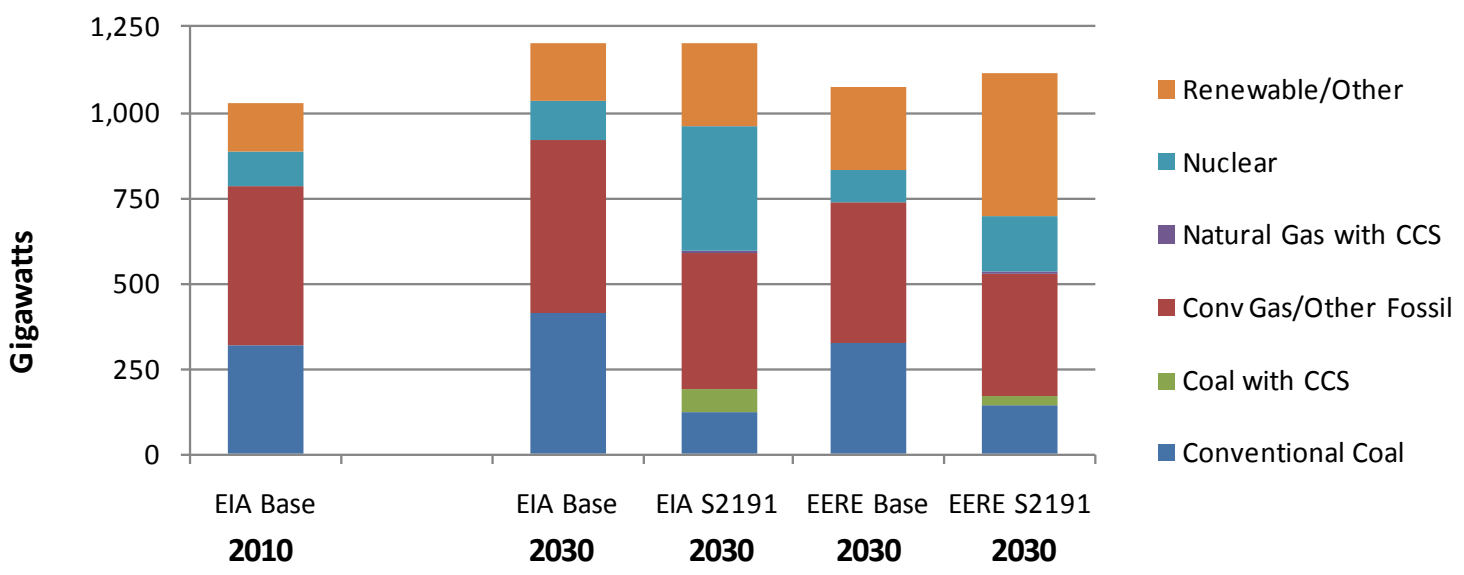

Figure 12. Electric generating capacity, including distributed generating capacity

Figure 13 illustrates the change in total renewable electric capacity as well as the mix of renewable technologies under each scenario. Renewable capacity in 2030 in the EERE S. 2191 Case is almost 75 percent greater than the capacity in the EIA S. 2191 Case, increasing from $239 \mathrm{GW}$ (20 percent of total capacity) to $413 \mathrm{GW}$ (37 percent of total capacity). In the EIA S. 2191 Case, biomass and land-based wind are the dominant-growth renewable technologies, whereas the EERE S. 2191 Case favors land-based wind and distributed PV. ${ }^{25}$ These results depend heavily upon the technology assumptions, but EERE RD\&D programs aim to reduce the cost of these technologies and improve their performance, making them more attractive especially in a carbon-constrained scenario.

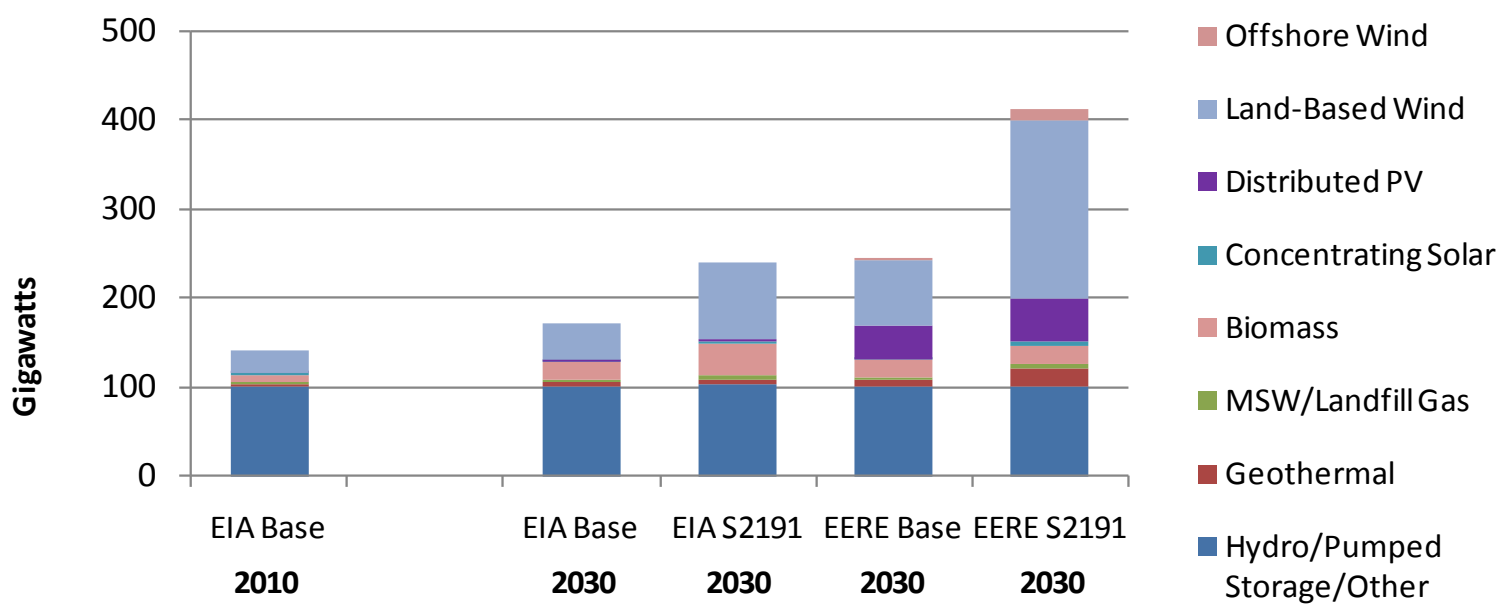

Figure 13. Renewable electric capacity, including distributed generating capacity

Figure 14 provides a complete picture of the ability of EERE programs to both reduce electricity demand through efficiency programs and increase renewable generation by lowering the costs and improving the availability of these technologies. While the EIA S. 2191 Case relies heavily on the construction of large-scale nuclear plants to meet the bill's requirements, the combination of demand reductions and low-cost renewables greatly reduces the need for new nuclear facilities in the EERE S. 2191 Case. At the same time, the share of renewable generation increases from 19 percent of total generation in EIA S. 2191 to 39

\footnotetext{
${ }^{25}$ Distributed PV is rooftop solar panels purchased by homes and businesses.
} 
percent in EERE S. 2191. Renewable generation is currently about 11 percent of total generation.

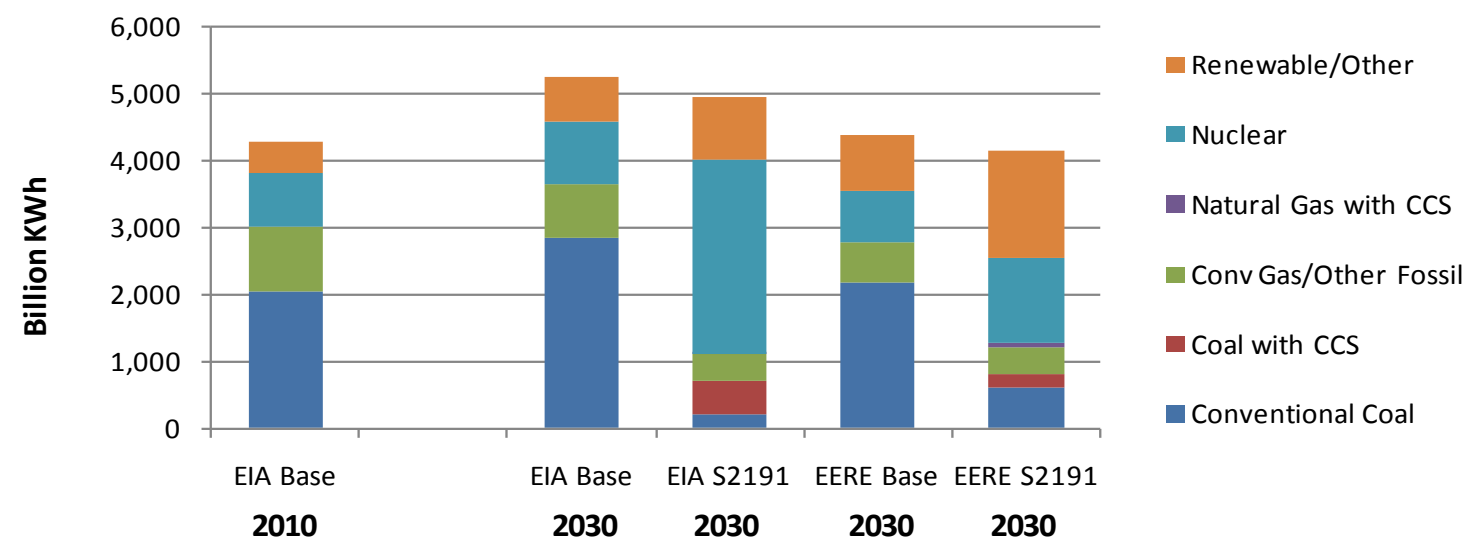

Figure 14. Electricity generation, including distributed generating capacity

\section{Residential and Commercial Buildings and Industrial Sectors}

As shown in Figure 15, delivered energy consumption in residential and commercial buildings (primarily natural gas and electricity) in the EERE S. 2191 Case is almost 18 percent below the EIA Base Case by 2030, and is 1.5 percent below current consumption levels, due to efficiency improvements attributed to the Building Technologies in conjunction with the higher energy prices of the climate policy. Energy consumption in the EERE Base Case alone is about 13 percent below the EIA Base Case. Space heating and cooling contributed about 30 percent of total savings; water heating and lighting contributed another 23 percent of savings; the remaining savings come from a variety of other devices such as televisions, clothes washers and dryers, personal computers, and battery chargers.

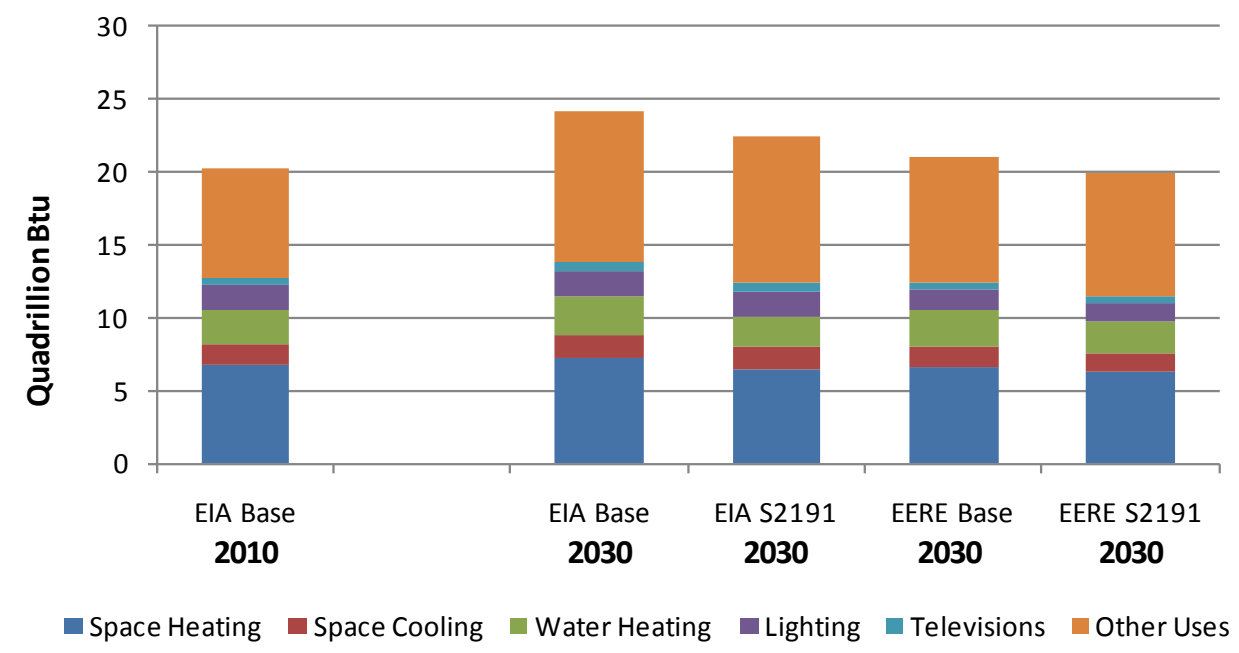

Figure 15. Buildings delivered energy consumption

Delivered energy consumption in the industrial sector declined in both of the EERE cases relative to the EIA Base Case by 2030, as shown in Figure 16. Most of the reductions are from savings in natural gas consumption that are due to EERE improvements in energy 
efficiency. Energy consumption in the EERE cases is also below current levels by 2030, whereas consumption continues to increase over time in the EIA cases. Industrial electrification (coupled with electric sector decarbonization) has been proposed as a carbon mitigation strategy, but this study did not explicitly examine this strategy.

Although coal represents a small share of industrial energy consumption, industrial coal use declines, mainly because of reductions in coal-fired boilers and coal-to-liquids production, by 32 percent in the EIA S. 2191 Case and by almost 40 percent in the EERE S. 2191 Case compared to the EIA Base Case by 2030. About two-thirds of the industrial direct (i.e., nonelectric) emissions reductions are due to coal savings.

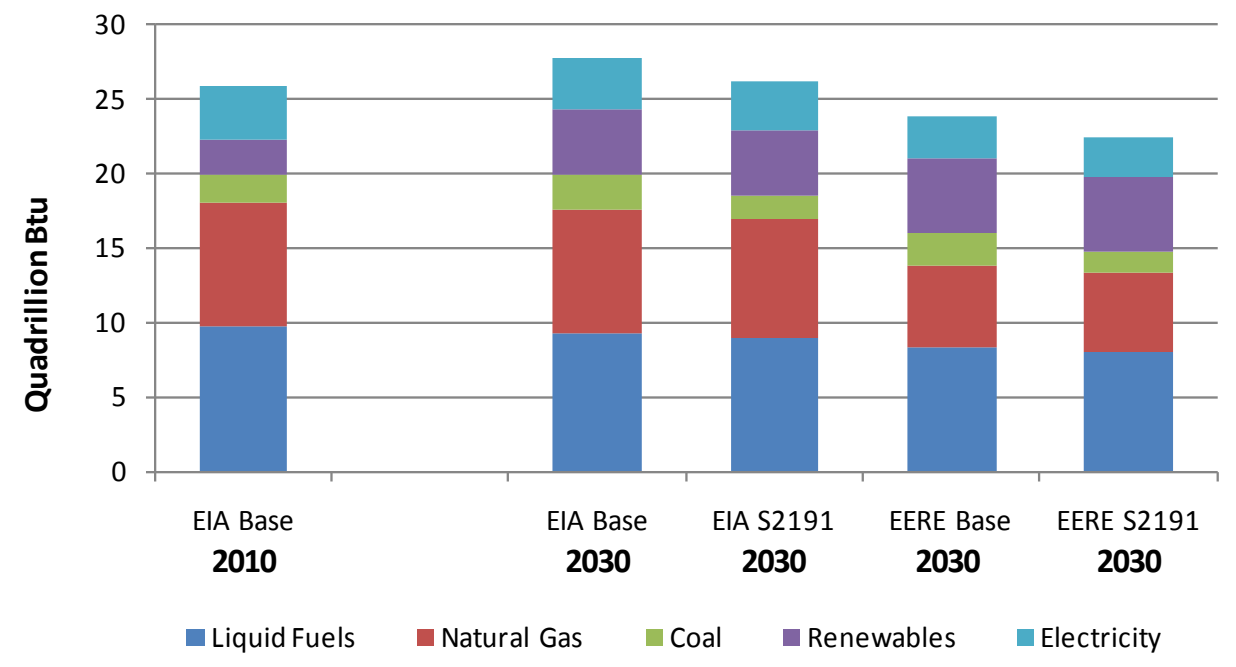

Figure 16. Industrial delivered energy consumption

\section{Transportation Sector}

Transportation energy consumption in the EERE S. 2191 Case declined about 1.8 quadrillion Btu (quads) or 6 percent from the EIA Base Case by 2030, primarily due to assumed improvements in light-duty vehicle (LDV) and heavy-duty vehicle energy efficiency, as shown in Figure 17 and Figure 18. Light-duty vehicles and heavy-duty vehicles (freight trucks and buses) consume almost 80 percent of total transportation sector energy (primarily liquid fuels). The S. 2191 Cases also showed reduced energy consumption from rail (due to less coal consumption by electric generators) and from natural gas pipelines, which is included in the "Other" category. 


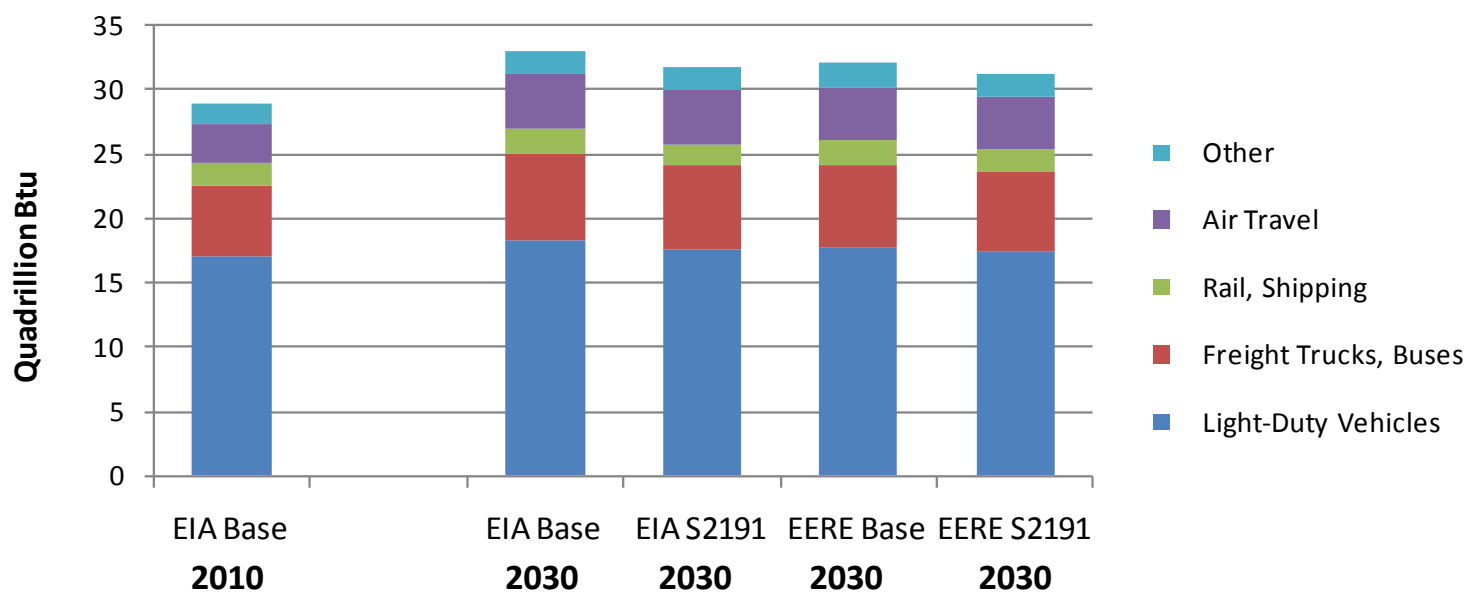

Figure 17. Transportation energy consumption by mode

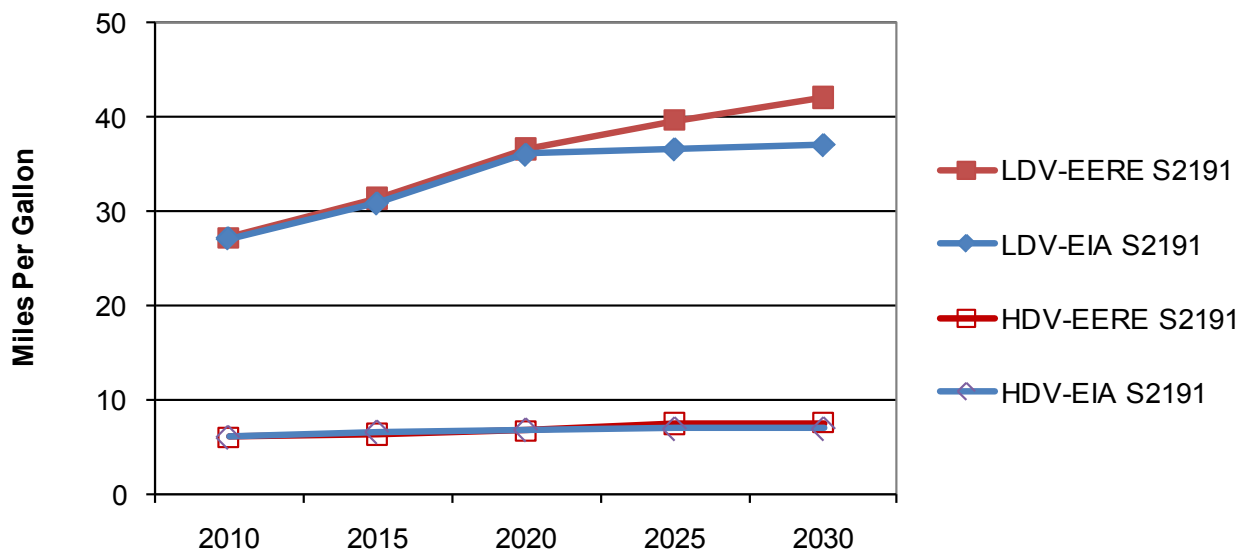

Figure 18. Fuel efficiency for new light-duty and heavy-duty vehicles

As illustrated in Figure 18, average fuel efficiency for new LDVs improved 15 percent in the EERE S. 2191 Case by 2030, from an average of 37 miles per gallon (mpg) in the EIA S. 2191 Case to $42 \mathrm{mpg}$ with the EERE programs. Average fuel efficiency for new heavyduty vehicles increased about 8 percent between the two cases, from $7.0 \mathrm{mpg}$ to $7.5 \mathrm{mpg}$ in the EERE cases. Average LDV stock efficiency improved at a slower pace, from $28 \mathrm{mpg}$ in the Base Case to $30 \mathrm{mpg}$ by 2030, due to the rate of vehicle stock turnover. The current average fuel efficiency is $27 \mathrm{mpg}$ for new light-duty vehicles, and the new CAFE standards passed by Congress as part of the Energy Independence and Security Act of 2007 (EISA) ${ }^{26}$ require that the combined average fuel efficiency of LDVs reach $35 \mathrm{mpg}$ by 2020.

The EIA Base and S. 2191 Cases are virtually identical for vehicle fuel efficiency because gasoline and diesel fuel prices only increase roughly 50 cents per gallon by 2030 due to S. 2191 and because CAFE standards mandated under EISA are binding in these cases. The increased fuel economy in the EERE cases is primarily due to improvements in and greater adoption of advanced diesel and hybrid vehicles (including plug-in hybrid electric vehicles or

\footnotetext{
${ }^{26}$ The full text of EISA can be found on the Library of Congress' THOMAS Web site (http://thomas.loc.gov/).
} 
PHEVs) and advanced materials. PHEVs' level of emissions depends not only on fuel efficiency but also on the carbon content of the electricity they use.

The share of advanced technology vehicles, shown in Figure 19, increased from 35 percent of total LDV stock in the EIA cases to 50 percent in the EERE cases by 2030, mainly due to increases in hybrid vehicles and advanced diesel. These results suggest that S. 2191 provisions alone are not enough to increase the share of advanced technologies in LDVs, whereas EERE programs can do so.

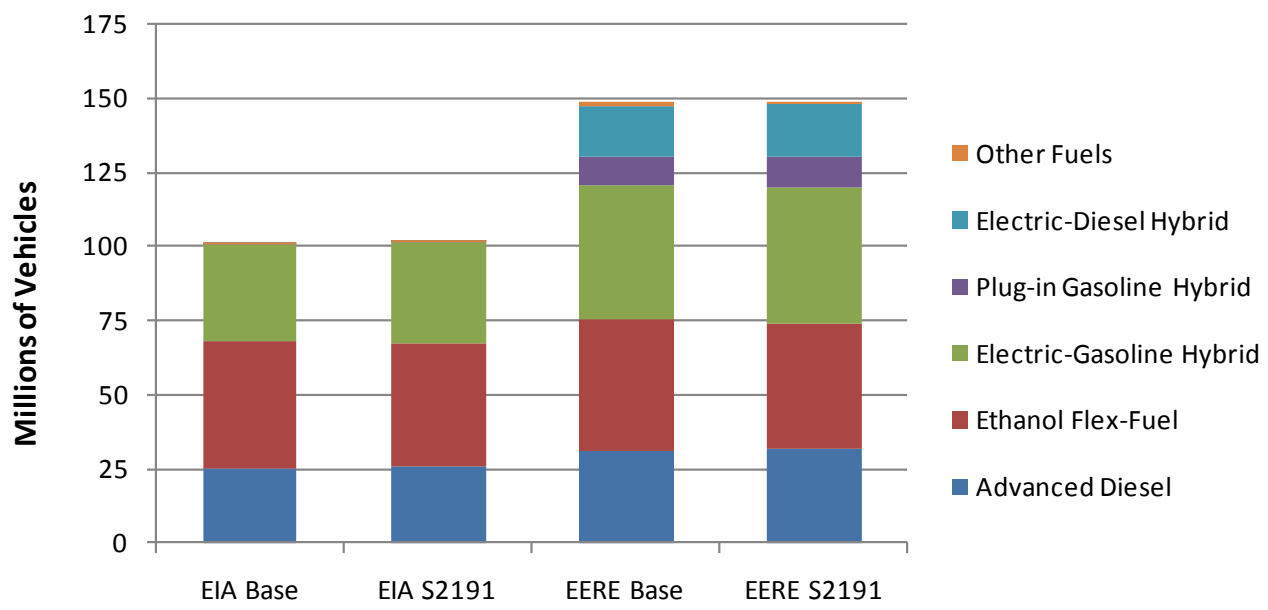

Figure 19. Advanced technology LDV stock in 2030

The Renewable Fuel Standard (RFS) of EISA stimulates additional ethanol production, although in all scenarios, the total biofuels quantity falls short of the 36 billion gallon required by 2022 because assumptions in the model do not force this requirement to be met. The effect of EERE RD\&D programs dramatically increases the share of cellulosic ethanol in the EERE S. 2191 Case, from 29 percent of ethanol production in the EIA Base to 75 percent by 2030; it also increases total ethanol production. As shown in Figure 20, corn ethanol production in the EERE S. 2191 Case declines between 2020 and 2030 but remains constant at 15 billion gallons in both EIA cases as part of meeting the RFS. Total ethanol production increases 18 percent in the EERE S. 2191 Case compared to the EIA Base Case by 2030 due to lower ethanol costs stimulating greater E85 demand. ${ }^{27}$

\footnotetext{
${ }^{27} \mathrm{E} 85$ is a blend of 85 percent ethanol and 15 percent gasoline by volume.
} 


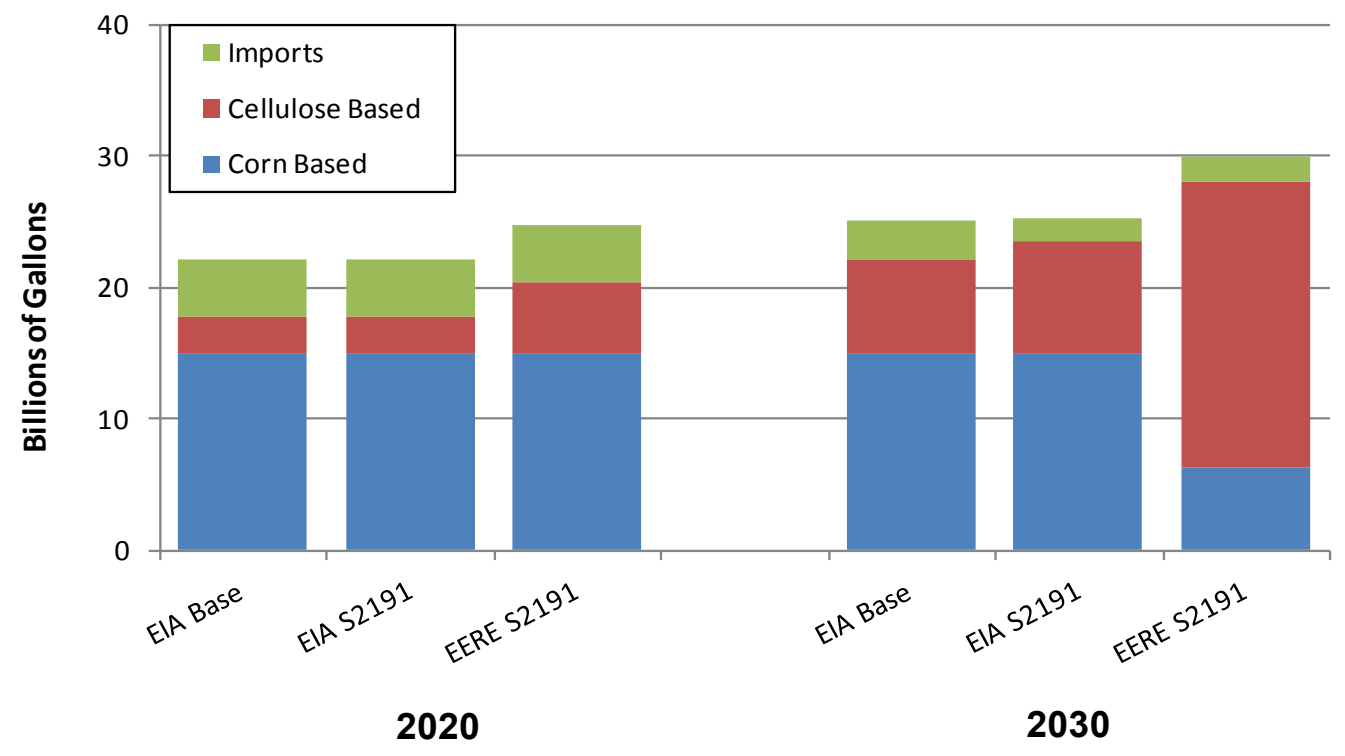

Figure 20. Ethanol production by source 


\section{Conclusions and Insights}

This study analyzed the projected effects of EERE RD\&D programs on energy consumption, technology choice, and associated greenhouse gas emissions in the United States under a carbon constraint. We compared cases in which EERE program goals were achieved to cases in which they were not achieved, in cases both with and without a cap on greenhouse gas emissions, using NEMS-EERE to model each case.

EERE programs, if successful, are expected to increase the efficiency of the energy system and decrease the cost of renewable generation and transportation biofuels. With our assumptions, EERE programs reduced greenhouse gas allowance prices by almost 35 percent by 2030, compared to EIA's estimate of the impact of the S. 2191 proposal using business-asusual technology assumptions. Delivered energy consumption was reduced 9 percent, and renewable generation increased 70 percent by 2030 compared to the EIA S. 2191 Case; consumption was reduced 13 percent, and renewable generation more than doubled compared to the EIA Base Case.

The electricity sector accounted for the largest share of emissions reductions in both the EIA and EERE S. 2191 Cases due to a combination of fuel switching to low-carbon sources of electricity and energy efficiency improvements by the end-use sectors. Because the electric industry depends on carbon-rich coal and is the primary consumer of coal used in the United States, it is able to reduce emissions substantially by switching away from coal to other fuels through a combination of plant dispatch and capacity investment decisions. The residential, commercial, and industrial sectors contribute to electric sector reductions by purchasing efficient electrical equipment, and by reducing their demand for energy services. Achieving EERE program goals would reduce costs and improve adoption of energy efficient technologies and practices.

The transportation sector depends on carbon-rich petroleum products, and currently has limited cost-effective options for fuel switching. However, the EERE Vehicle Technologies and Biomass Programs are working to expand transportation options for advanced vehicles and fuels. Despite substantial penetration of advanced technology vehicles and biofuels in the EERE cases, transportation sector emissions reductions were more expensive to achieve than electric sector emissions reductions were under the assumptions and timeframe of this study. S. 2191 alone did not provide enough incentive to reduce transportation emissions much beyond what was achieved in the EERE Base Case. More targeted incentives are needed to substantially reduce emissions from this sector, and EERE programs can provide the necessary technologies to enable those incentives.

Implications of EERE programs are evident in the roles of biomass and PHEVs. With EERE RD\&D success in the Biomass Program, biomass plays a more significant role in ethanol production and less in power production, with the reduced role in power production attributable in part to competition from other low-cost renewable generation technologies. PHEVs also play a role in reducing greenhouse gas emissions. The ability for plug-in hybrids to reduce emissions improves as the carbon content of electricity declines; this has only a modest benefit by 2030 but could become more important post-2030, especially in a carbonconstrained policy. 
EERE Vehicle Technologies, Industrial Technologies, and Building Technologies Programs were shown to significantly reduce or even reverse the trend of energy demand growth in the next 20 years. The carbon policy alone was not enough to reverse these trends or improve vehicle efficiencies without the success of these programs.

EERE programs, if successful, will reduce the marginal cost of $\mathrm{CO}_{2}$ emissions reductions, reflected in the allowance price, which in turn will reduce fuel prices for households and businesses, notably electricity generators. Lower fuel prices will reduce the need for generators to retire existing power plants, while the electricity savings from the RD\&D programs will reduce the need to build new generating capacity. When new capacity is needed, generators will have low-cost renewable technologies available to meet the emissions cap. Successful achievement of these RD\&D goals thus enhances the ability of the U.S. economy to thrive while simultaneously mitigating greenhouse gas emissions. 
PLEASE DO NOT RETURN YOUR FORM TO THE ABOVE ORGANIZATION.

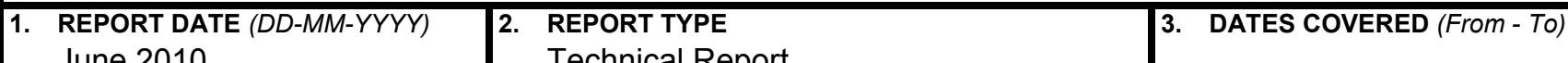
June 2010

Technical Report

4. TITLE AND SUBTITLE

Energy Efficiency and Renewable Energy Research, Development, and Deployment in Meeting Greenhouse Gas Mitigation Goals: The Case of the Lieberman-Warner Climate Security Act of 2007 (S.2191)

6. AUTHOR(S)

S. Showalter, F. Wood, L. Vimmerstedt 5a. CONTRACT NUMBER

DE-AC36-08-GO28308

5b. GRANT NUMBER

5c. PROGRAM ELEMENT NUMBER

5d. PROJECT NUMBER

NREL/TP-6A2-47213

5e. TASK NUMBER

SAO9.1051

5f. WORK UNIT NUMBER

7. PERFORMING ORGANIZATION NAME(S) AND ADDRESS(ES)

National Renewable Energy Laboratory

1617 Cole Blvd.

8. PERFORMING ORGANIZATION REPORT NUMBER

NREL/TP-6A2-47213

Golden, CO 80401-3393

9. SPONSORING/MONITORING AGENCY NAME(S) AND ADDRESS(ES)

10. SPONSOR/MONITOR'S ACRONYM(S) NREL

11. SPONSORING/MONITORING AGENCY REPORT NUMBER

12. DISTRIBUTION AVAILABILITY STATEMENT

National Technical Information Service

U.S. Department of Commerce

5285 Port Royal Road

Springfield, VA 22161

\section{SUPPLEMENTARY NOTES}

\section{ABSTRACT (Maximum 200 Words)}

The U.S. federal government is considering actions to reduce greenhouse gas emissions. Renewable energy and energy efficiency technologies could help reduce greenhouse gas emissions, so the cost of these technologies could significantly influence the overall cost of meeting greenhouse gas limits. This paper examines the potential benefit of reduced technology cost by analyzing the case of the Lieberman-Warner Climate Security Act of 2007 (S.2191). This act had a goal of reducing national carbon emissions in 2050 to levels 72 percent below 2006 emission levels. In April 2008, the U.S. Department of Energy, Energy Information Administration (EIA) published an analysis of the effects of S.2191 on the U.S. energy sector. This report presents a similar analysis: both analyses examined the impacts of S.2191, and both used versions of the National Energy Modeling System. The analysis reported here used modified technology assumptions to reflect U.S. Department of Energy, Office of Energy Efficiency and Renewable Energy (EERE) program goals. The results show that achieving EERE program goals could reduce the cost of meeting greenhouse gas limits, reduce the cost of renewable electricity generation and biofuels, and reduce energy intensity.

15. SUBJECT TERMS

Lieberman-Warner Climate Security Act of 2007; S.2191; Senate Bill 2191; carbon emissions; greenhouse gas emissions; emission reductions; greenhouse gas allowance prices; energy intensity; carbon cap; technological change; research and development; renewable energy; energy efficiency; federal government

\begin{tabular}{|c|c|c|c|c|}
\hline \multicolumn{3}{|c|}{ 16. SECURITY CLASSIFICATION OF: } & \multirow{2}{*}{$\begin{array}{l}\text { 17. LIMITATION } \\
\text { OF ABSTRACT } \\
\text { UL }\end{array}$} & \multirow{2}{*}{$\begin{array}{ll}\text { 18. } & \text { NUMBER } \\
\text { OF PAGES }\end{array}$} \\
\hline $\begin{array}{l}\text { a. REPORT } \\
\text { Unclassified }\end{array}$ & $\begin{array}{l}\text { b. ABSTRACT } \\
\text { Unclassified }\end{array}$ & $\begin{array}{l}\text { c. THIS PAGE } \\
\text { Unclassified }\end{array}$ & & \\
\hline
\end{tabular}

19b. TELEPHONE NUMBER (Include area code) 